\title{
Distribution and Corticosteroid Regulation of Glucocorticoid Receptor in the Brain of Xenopus laevis
}

\author{
MENG YAO, FANG HU, AND ROBERT J. DENVER* \\ Department of Molecular, Cellular and Developmental Biology, The University of \\ Michigan, Ann Arbor, Michigan 48109-1048
}

\begin{abstract}
Glucocorticoids (GCs) play essential roles in physiology, development, and behavior that are mediated largely by the glucocorticoid receptor (GR). Although the GR has been intensively studied in mammals, very little is known about the GR in nonmammalian tetrapods. We analyzed the distribution and GC regulation of GR in the brain of the frog Xenopus laevis by immunohistochemistry. GR-immunoreactive (GR-ir) cells were widely distributed, with the highest densities in the medial pallium (mp; homolog of the mammalian hippocampus), accumbens, anterior preoptic area (POA; homolog of the mammalian paraventricular nucleus), Purkinje cell layer of the cerebellum, and rostral anterior pituitary gland (location of corticotropes). Lower but distinct GR-ir was observed in the internal granule cell layer of the olfactory bulbs, dorsal and lateral pallium, striatum, various subfields of the amygdala, bed nucleus of the stria terminalis (BNST), optic tectum, various tegmental nuclei, locus coeruleus, raphe nuclei, reticular nuclei, and the nuclei of the trigeminal motor nerves. Treatment with corticosterone (CORT) for 4 days significantly decreased GR-ir in the POA, mp, medial amygdala (MeA), BNST, and rostral pars distalis. Treatment with the corticosteroid synthesis inhibitor metyrapone (MTP) also significantly reduced GR-ir in the POA, mp, MeA and BNST, but not in the rostral pars distalis. Replacement with a low dose of CORT in MTP-treated animals reversed these effects in brain. Thus, chronic increase or decrease in circulating corticosteroids reduces GR-ir in regions of the frog brain. Our results show that the central distribution of GR-ir and regulation by corticosteroids are highly conserved among vertebrates. J. Comp. Neurol. 508:967-982, 2008. ๑ 2008 Wiley-Liss, Inc.
\end{abstract}

Indexing terms: glucocorticoid receptor; Xenopus; stress response; hypothalamus; limbic system; hippocampus; amygdala; pituitary

Glucocorticoids (GCs) exert diverse developmental, physiological, and behavioral actions in vertebrates (Chrousos, 1998; Chrousos and Gold, 1992). The production of GCs by cells of the adrenal cortex (interrenal glands in nonmammalian species) is controlled by pituitary adrenocorticotropic hormone (ACTH), whose synthesis and secretion is controlled by hypothalamic corticotropin-releasing factor $(\mathrm{CRF})$ and arginine vasopressin (AVP). Circulating GC concentration increases rapidly following exposure to stressors, which serves to coordinate physiological and behavioral adjustments to maintain homeostasis. Elevated circulating GC concentration exerts negative feedback at multiple levels of the hypothalamo-pituitary-adrenal (HPA) axis to prevent continued activation (Makino et al., 2002a).

The actions of GCs are mediated by two ligand-activated transcription factors that were originally identified in mammals based on their differential binding affinities: the high-affinity type I receptor (also called the "mineralocorticoid receptor"; MR; NR3C2) and the lower-affinity type II receptor (also called the "glucocorticoid receptor"; GR; NR3C1). The GR and MR belong to the nuclear hormone receptor superfamily, and phylogenetic analysis suggests that these two receptors arose by a gene dupli-

Grant sponsor: National Science Foundation; Grant number: IBN 0235401 (to R.J.D.).

*Correspondence to: Dr. Robert J. Denver, 3065C Kraus Natural Science Bldg., University of Michigan, Ann Arbor, MI 48109-1048.

E-mail: rdenver@umich.edu

Received 21 November 2007; Revised 31 January 2008; Accepted 13 February 2008

DOI 10.1002/cne.21716

Published online in Wiley InterScience (www.interscience.wiley.com). 
cation event in the gnathastome lineage (Bridgham et al., 2006; Thornton, 2001). In mammals, the MR is hypothesized to function in the maintenance of basal expression and the circadian rhythm of circulating GCs, whereas most GC-dependent physiological changes that occur in response to stressors, and feedback regulation by GCs is thought to be mediated by the GR (Bamberger et al., 1996; De Kloet et al., 1998; Wei et al., 2004). In the absence of ligand, the GR is located in the cytosol associated with heat shock proteins and immunophilins (referred to as the "foldosome"; Pratt and Toft, 1997). Ligand binding causes disassociation of the protein complex and translocation of GR into the nucleus, where GR regulates transcription of its target genes (Kumar and Thompson, 2005).

Full-length or partial cDNA sequences for the GR have been isolated from nonmammalian species, including birds (chicken, Kwok et al., 2007; zebra finch Taeniopygia guttata, Hodgson et al., 2007), fishes (the rainbow trout Onchorhynchus mykiss, Ducouret et al., 1995; tilapia Oreochromis mossambicus, Tagawa et al., 1997; Japanese flounder, Tokuda et al., 1999; fathead minnow Pimephales promelas, Filby and Tyler, 2007), and frog Xenopus laevis, Gao et al., 1994), and are highly conserved. These genes were isolated and named based on their sequence similarity to the mammalian GR (Gao et al., 1994; Thornton, 2001). The primary amino acid sequences of the DNA binding domains of $X$. laevis and human GR are identical, and the hormone binding domains share $86 \%$ similarity. The N-terminal domains of frog and mammalian GR proteins are less well conserved, sharing 51\% similarity at the amino acid level (Gao et al., 1994). The $X$. laevis GR (xGR), when expressed in COS cells, was capable of mediating hormone-dependent transactivation of a GREcontaining promoter to an extent similar to that of the rat GR (Gao et al., 1994). These data suggest that the structure and function of GR are evolutionarily conserved among vertebrate species.

GR receptor protein and mRNA are widely distributed in the central nervous system (CNS) of rodents (Ahima and Harlan, 1990; Morimoto et al., 1996). The highest levels of GR immunoreactivity (GR-ir) and mRNA were found in the cerebral cortex, olfactory pyramidal layers, hippocampal formation, paraventricular nucleus (PVN), medial and central nuclei of the amygdala, granule layer of the cerebellar cortex, and locus coeruleus (Ahima and Harlan, 1990; Morimoto et al., 1996). The hippocampus expresses the highest level of GR in the mammal brain, and GC actions here lead to tonic inhibition of neurosecretory neurons in the PVN via descending inhibitory projections to down-regulate the activity of the HPA axis (Herman et al., 2005). The PVN neurons also express a high level of GR and thus are direct targets for circulating GCs (Makino et al., 2002a). GCs influence cognition via actions on the hippocampus and amygdala (Lupien and McEwen, 1997; Sapolsky, 2003).

Relatively little is known about the central distribution of GR in nonmammalian species. To our knowledge, nothing is known about GR distribution in amphibians or reptiles. Except for one report on GR-like immunoreactivity in the Japanese quail (Kovács et al., 1989), studies on the central distribution of GR in nonmammalian vertebrates have been conducted with teleost fishes. In the rainbow trout (Oncorhynchus mykiss), among the brain regions where GR-ir was observed, the highest densities were found in the ventral telencephalon, preoptic region, mediobasal hypothalamus, and optic tectum (Teitsma et al., 1998). Lower densities of GR were seen in the internal cell layer of the olfactory bulb and lateral regions of the dorsal telencephalon (Teitsma et al., 1998; see also Carruth et al., 2000, for a study in kokanee salmon). The generally conserved central distribution of GR in fishes and mammals suggests that expression and function of GR in the CNS arose early in vertebrate evolution and may be conserved.

In an effort to understand the evolutionary origins of GC targets in the CNS, and the roles of GCs in development, physiology, and behavior in extant species, we analyzed the distribution of GR-ir and GR regulation by GCs in the brain and pituitary gland of the frog $X$. laevis, an important model organism in endocrinology and developmental biology. We found that the pattern of GR-ir distribution in the frog brain and pituitary gland is highly conserved with mammals and fishes. We provide the first detailed map of GR-ir distribution in the CNS of a non-

Abbreviations

$\begin{array}{ll}\text { A } & \text { anterior thalamic nucleus } \\ \text { Acc } & \text { nucleus accumbens } \\ \text { BNST } & \text { bed nucleus of the stria terminalis } \\ \text { Cb } & \text { cerebellum } \\ \text { CeA } & \text { central amygdala } \\ \text { dp } & \text { dorsal pallium } \\ \text { Hd } & \text { dorsal habenular nucleus } \\ \text { Hv } & \text { ventral habenular nucleus } \\ \text { IIIv } & \text { third ventricle } \\ \text { igl } & \text { internal granule cell layer } \\ \text { Is } & \text { nucleus isthmi } \\ \text { L } & \text { lateral thalamic nucleus } \\ \text { LA } & \text { lateral amygdala } \\ \text { Lc } & \text { locus coeruleus } \\ \text { lp } & \text { lateral pallium } \\ \text { LPv } & \text { lateral thalamic nucleus } \\ \text { ls } & \text { lateral septum } \\ \text { lv } & \text { lateral ventricle } \\ \text { ME } & \text { median eminence } \\ \text { MeA } & \text { medial amygdala } \\ \text { ml } & \text { mitral layer } \\ \text { mp } & \text { medial pallium }\end{array}$

$\begin{array}{ll}\text { ms } & \text { medial septum } \\ \text { nII } & \text { cranial nerve II } \\ \text { P } & \text { posterior thalamic nucleus } \\ \text { pd } & \text { pars distalis } \\ \text { pi } & \text { pars intermedia } \\ \text { pn } & \text { pars nervosa } \\ \text { POA } & \text { preoptic area } \\ \text { Ra } & \text { raphe nucleus } \\ \text { Ri } & \text { inferior reticular nucleus } \\ \text { Rm } & \text { nucleus reticularis medius } \\ \text { SC } & \text { suprachiasmatic nucleus } \\ \text { Str } & \text { striatum } \\ \text { tect } & \text { optic tectum } \\ \text { tegm } & \text { mesencephalic tectum } \\ \text { Tn } & \text { tegmental nuclei } \\ \text { TP } & \text { posterior tuberculum } \\ \text { VH } & \text { ventral hypothalamic nucleus } \\ \text { VLs } & \text { superficial ventral nucleus } \\ \text { VM } & \text { ventromedial thalamic nucleus } \\ \text { Vm } & \text { nucleus motorius nervi trigemini } \\ \text { Vpr } & \text { nucleus sensorius principalis nervi trigemini }\end{array}$


mammalian tetrapod and show that GR expression in the frog is modulated by GCs, as it is in mammals, suggesting that this pathway for regulation of the HPA axis is an ancient and conserved character of the vertebrate lineage.

\section{MATERIALS AND METHODS Animal husbandry}

Xenopus laevis juvenile and adult frogs were purchased from Xenopus I (Dexter, MI). Frogs were maintained in the laboratory in well water $\left(20-22^{\circ} \mathrm{C}\right)$ under a $12 \mathrm{~L}: 12 \mathrm{D}$ photoperiod and fed beef liver. All procedures involving animals were conducted in accordance with the guidelines of the University Committee on the Care and Use of Animals of the University of Michigan.

\section{Production and purification of polyclonal antiserum to $X$. laevis GR}

We generated a polyclonal antiserum to the $\mathrm{A} / \mathrm{B}$ region of $X$. laevis GR in rabbit (Lampire Biological, Downingtown, PA) using a synthetic peptide corresponding to amino acids 8-25 of xGR (KPSSGSPAVRGSPHYNDK) conjugated to keyhole limpet hemocyanin. We used an online computer program available through the Harvard University Cancer Vaccine Center (http://bio.dfci.harvard.edu/Tools/antigenic.pl) to identify antigenic regions of the full-length frog GR protein. The length and sequence of the $\mathrm{N}$-terminal $\mathrm{A} / \mathrm{B}$ regions are highly variable among nuclear hormone receptors (Germain et al., 2006), and the peptide sequence that we chose shows no sequence similarity to other known frog steroid hormone receptors (analyzed by alignment of amino acid sequences of $X$. laevis mineralocorticoid, androgen, estrogen, progesterone, and thyroid hormone receptors using the AlignX module of the Vector NTI Suite software program; Invitrogen, Carlsbad, CA). BLAST search of the NCBI database showed no sequence similarity of the xGR peptide sequence to other known proteins. We purified the antiserum over an Affi-Gel Protein A column, followed by affinity purification over a peptide affinity column with the $x$ GR antigenic peptide conjugated to Ultralink iodoacetyl matrix (Pierce, Rockfold, IL), following the manufacturer's instructions. The concentration of the purified IgG was determined by the BCA Protein Assay (Pierce).

\section{Western blotting analysis}

We conducted Western blotting analysis using in vitrosynthesized xGR protein or whole-cell extract of XTC-2 cells (X. laevis carcass cell; Pudney et al., 1973). We produced $x G R$ protein using the p6xGR vector (Gao et al., 1994) and the TNT system (Promega, Madison, WI), following the manufacturer's protocols. We included [ $\left.{ }^{35} \mathrm{~S}\right] \mathrm{me}-$ thionine + cysteine (EasyTag EXPRESS ${ }^{35}$ S protein labeling mix; Perkin Elmer, Waltham, MA) in the in vitro transcription-translation reaction, which we then analyzed by $10 \%$ sodium dodecyl sulfate (SDS)-polyacrylamide gel electrophoresis (PAGE), followed by fluorography. After running, the gel was fixed, impregnated with Enhance autoradiography enhancer (Perkin Elmer), dried, and exposed to X-ray film.

Protein samples were boiled in SDS sample buffer (containing $0.5 \%$ SDS, $0.15 \mathrm{mM}$ Tris base, $2.5 \%$ glycerol, and $0.0125 \%$ bromophenol blue; $\mathrm{pH}$ 6.8) for 5 minutes, then separated on a $10 \%$ SDS-polyacrylamide gel. The proteins were electophoretically transferred to nitrocellulose membranes (Trans-Blot Transfer Medium; Bio-Rad, Hercules, CA) using a Trans-Blot SD transfer cell (Bio-Rad). Membranes were blocked in phosphate-buffered saline (PBS) with $0.05 \%$ Tween-20 (PBST; pH 7.4), 5\% bovine serum albumin (BSA; Sigma, St. Louis, MO), and 10\% normal goat serum overnight at $4^{\circ} \mathrm{C}$, then incubated with affinitypurified rabbit anti-xGR IgG $(0.5 \mu \mathrm{g} / \mathrm{ml}$ in PBST with $5 \%$ BSA) overnight at $4^{\circ} \mathrm{C}$. After washes in PBST, immunopositive bands were visualized using the ECL Western blotting system (Amersham, GE Healthcare, Buckinghamshire, United Kingdom).

\section{Cell culture and GC treatment}

Monolayer cultures of the $X$. laevis kidney cell line A6 were maintained in Leibovitz's L15 medium (Invitrogen; diluted 1:1.5 for amphibian cells, $\mathrm{pH}$ 7.4) supplemented with $10 \%$ steroid hormone-stripped fetal bovine serum (Life Technologies, Grand Island, NY) and antibiotics. Steroid hormone removal from fetal bovine serum was conducted by mixing $25 \mathrm{ml}$ serum with $50 \mathrm{mg}$ charcoal [coated with $5 \mathrm{mg}$ Dextran T 70 (Pharmarcia Biotech, Uppsala, Sweden) in PBS, $\mathrm{pH}$ 7.4] and shaking at room temperature for 5 hours, followed by centrifugation at $1,000 \mathrm{~g}$ for 10 minutes. The supernatant was mixed again with $50 \mathrm{mg}$ charcoal-Dextran and shaken at room temperature overnight before a final centrifugation at $30,000 \mathrm{~g}$ for $20 \mathrm{~min}-$ utes at $4^{\circ} \mathrm{C}$.

The A6 cells were plated on glass slides and cultured under a humidified atmosphere of $5 \% \mathrm{CO}_{2}$ at $25^{\circ} \mathrm{C}$. Cells were incubated with $100 \mathrm{nM}$ dexamethasone (Sigma), 100 $\mathrm{nM}$ corticosterone (Sigma), or vehicle $(0.001 \%$ ethanol) in growth medium for 1.5 hours. Then, cells were fixed in $4 \%$ paraformaldehyde and processed for immunohistochemical analysis of GR (see below).

\section{Immunohistochemistry}

We used immunohistochemistry (IHC), following methods described previously (Yao et al., 2004), to analyze the distribution of GR-ir in the $X$. laevis brain. Single IHC for GR-ir was conducted using the Vectastain Elite ABC (rabbit) and Vector VIP kits, following the manufacturer's instructions (both from Vector, Burlingame, CA; $0.5 \mu \mathrm{g} / \mathrm{ml}$ affinity-purified polyclonal rabbit anti-xGR IgG). The specificity of the affinity-purified anti-xGR IgG was tested by preabsorption with the antigenic xGR peptide or with unrelated peptides corresponding to three regions of the frog MR. The MR peptides used corresponded to amino acid positions $6-45,32-49$, and $160-177$ of the $X$. laevis MR protein and share no sequence similarity with the antigenic $x G R$ peptide. The antibodies were incubated with peptides $(10 \mathrm{ng} / \mu \mathrm{l})$ overnight at $4^{\circ} \mathrm{C}$ before IHC. Micrographic images were captured using an Olympus IX81 inverted microscope and a Retiga 1300R fast digital video camera. Brightness, contrast, and evenness of illumination were adjusted uniformly for images shown in the figures in Adobe Photoshop CS2; images used for morphometric analysis (see below) were not adjusted.

Corticosterone and metyrapone treatment of juvenile $X$. laevis. For each treatment group, six juvenile frogs $(20-31 \mathrm{~g} \mathrm{BW})$ were placed into $30 \times 20 \times 20 \mathrm{~cm}$ tanks containing 5 liters of water, and the tanks were shielded to minimize disturbance by investigators. The frogs were maintained with husbandry conditions described above. Corticosterone (CORT; Sigma) and me- 
tyrapone (MTP; Sigma) were first dissolved in ethanol and added to the aquarium water to the appropriate final concentrations. The vehicle ethanol was adjusted to a final concentration of $0.0005 \%$ in all tanks, including the controls. The CORT-treated group received $500 \mathrm{nM}$ CORT in the aquarium water for 4 days (treatment started on day 1 , and frogs were killed on day 5). This dose of CORT produced a stress level plasma CORT concentration (see Results). The water was changed on day 3 , and CORT was added to the water daily. The whole-body CORT content in Xenopus tadpoles, and the nominal concentration of CORT in the aquarium water decrease to less than $10 \%$ of the starting values by $24 \mathrm{hr}$ following addition of the hormone (Krain and Denver, 2004; data not shown), so we added the hormone to the tanks without water change on days 2 and 4. This served to minimize disturbance to the animals. The MTP-treated group was exposed to $110 \mu \mathrm{M}$ MTP for 5 days; treatment was started on day 1 , and frogs were killed on day 6 . This dose of MTP was chosen because it decreases CORT to undetectable levels in $X$. laevis but does not cause overt toxicity (Glennemeier and Denver, 2002). MTP was added on day 1 and day 3 at the time of water change. For the MTP + CORT treatment, frogs were treated with $110 \mu \mathrm{M}$ MTP for 1 day, followed by MTP plus a replacement dose of $50 \mathrm{nM}$ CORT for 4 days. This dose of CORT produced a plasma CORT concentration similar to basal, unstressed levels in MTP-treated animals (see Results). The MTP and CORT were added to the aquarium water in the same manner as the single-drug treatments described above. All frogs were rapidly killed between 1300 and 1500 hours by submersion in $0.05 \%$ benzocaine, followed by decapitation, and tissues were collected. Blood was collected and plasma separated for CORT radioimmunoassay (see below). The heads were fixed in cold $4 \%$ paraformaldehyde overnight. Brains were dissected, postfixed in cold $4 \%$ paraformaldehyde for 1-2 hours, and submerged in $30 \%$ sucrose before snap freezing and transverse cryosectioning at $10 \mu \mathrm{m}$.

Shaking/handling stressor. Juvenile $X$. laevis were subjected to a shaking/handling stressor as previously described (Yao et al., 2004). Briefly, frogs were placed into 32-oz. white polypropylene containers, with two or three frogs in $250 \mathrm{ml}$ water. The containers were placed on an orbital shaker and shaken continuously at $100 \mathrm{rpm}$ for 6 hours. The frogs were killed by immersion in $0.05 \%$ benzocaine, and blood was collected for CORT radioimmunoassay (RIA).

\section{Plasma corticosterone RIA}

CORT was measured in frog plasma by using methods described by Licht et al. (1983). Briefly, plasma was extracted using diethyl ether, and the RIA was conducted using a corticosterone antiserum purchased from MP Biomedicals (Orangeburg, NY). All samples were measured in a single assay, and intraassay coefficient of variation was $10 \%$.

\section{Morphometric analysis of GR immunoreactivity}

We quantified GR-ir in discrete brain regions using the MetaMorph software package (v 6.2r4; Universal Imaging Corp., Downingtown, PA). We processed all samples simultaneously under identical conditions. With the anatomical definitions of Tuinhof et al. (1998) and Marín et al. (1998; see Fig. 4), we selected for analysis three to five coronal sections from each animal that contained the POA, amygdala, and bed nucleus of the stria terminalis (BNST) or medial pallium (mp); the number of sections analyzed depended on the size of the brain region. These brain regions were selected because of their strong GR-ir, suggesting that they are important targets for GC actions, and their known roles in the regulation of the HPA axis. All sections were carefully matched for anatomical level, and digital images were captured at $\times 100$ magnification for morphometric analysis. Image analysis was conducted in a blinded manner. We isolated brain regions on the captured images with a hand-made frame that covered the area of interest. Each selected brain region analyzed on adjacent sections and from different brains was roughly equivalent in total area, but, because each sample differed slightly in shape, we drew boxes by hand around each region of interest. Using the "Auto threshold for dark objects" tool in the Metamorph software, we adjusted the threshold to eliminate background staining. This was repeated on five to eight sections, and a mean threshold was established that was then set for analysis of all sections. The signal density within a selected area was then counted automatically. The signal density was divided by the total area of the selected brain region to obtain a mean signal density, which allowed for correction for size differences between brains and between adjacent sections. The average of the mean densities in a given brain region on replicate brain sections was calculated, summed for all animals in the treatment, then divided by the number of animals in the treatment to obtain the average signal density for each brain region (see Yao et al., 2004, 2007).

\section{RNA extraction and real-time RT- quantitative PCR analysis}

We analyzed GR mRNA expression in microdissected regions of the frog brain by $\mathrm{RTqPCR}$ as described previously (Yao et al., 2007). For the analysis of the distribution of $G R$ mRNA in the frog brain, we chose adult frogs because of their larger brains, which allowed for finer dissection of brain regions compared with juvenile frogs. Because the adult frogs were sexually mature, we compared males and females $(n=5 /$ sex $)$.

To analyze the effects of corticosteroid manipulations on $G R$ mRNA, we dissected the telencephalon/preoptic region from juvenile frogs treated with CORT or MTP as described above. We isolated total RNA from individual tissues using the Trizol reagent (Invitrogen). First-strand cDNA was synthesized with SuperScript II Reverse Transcriptase (Invitrogen) and random hexamers, following the manufacturer's instructions. We designed a genespecific Taqman primer/probe set for $X$. laevis $G R$ that spanned an intron/exon boundary: forward primer: $5^{\prime}$ CTGGCAGCGCTTTTACCAA-3', reverse primer: 5'-ATTCTCAGCCACCTCATGCAT-3'; probe: 6FAM-TGACAAAGCTATTGGACTC-MGQ. Reactions were run with the Fast 7500 Real-Time PCR System (Applied Biosystems, Foster City, CA), and we used a relative quantitation method by generating a standard curve with a pool of cDNA from the tissue with the highest level of expression (the telencephalon). The GR mRNA expression level was normalized to the expression of the $X$. laevis ribosomal protein L8 mRNA as previously described (Yao et al., 2007). 


\section{Statistical analysis}

We analyzed the data in Systat v10 statistical software (SPSS Inc., Chicago, IL). Data were $\log _{10}$ transformed before statistical analysis when the variances were found to be heterogeneous (Bartlett's test). Treatment effects on mean GR-ir signal density, plasma corticosterone, or $G R$ mRNA were analyzed by one-way ANOVA followed by Fisher's least squares differences (LSD) multiplecomparisons test. The data presented in the graphs are the mean $\pm \mathrm{SEM}$, and $P<0.05$ was considered statistically significant.

\section{RESULTS \\ Production and verification of the specificity of affinity-purified xGR antiserum}

We generated a polyclonal antiserum in rabbit against a short peptide conjugated to keyhole limpet hemocyanin that is located in the $\mathrm{N}$-terminal region of $\mathrm{xGR}$ (amino acid residues $8-25$ ). To enhance the specificity of the reagent we purified the antiserum by affinity chromatography (see Materials and Methods). The specificity of the affinitypurified xGR antibodies was first examined by Western blotting with in vitro-expressed xGR. A single ${ }^{35} \mathrm{~S}$-labeled protein of the expected MW $(96 \mathrm{kD})$ was produced by in vitro synthesis (Fig. 1A). A protein of a similar MW was recognized by Western blotting in the p6xGR programmed, but not in the unprogrammed TNT rabbit reticulocyte lysate reaction (Fig. 1B). The two smaller-MW bands observed in both lanes of the Western blot represent the IgG heavy and light chains present in the rabbit reticulocyte lysate and recognized by the goat anti-rabbit secondary antibody.

We conducted immunocyctochemistry on A6 cells ( $X$. laevis kidney cells that express GR; Claire et al., 1989; Watlington et al., 1982) using the same affinity-purified antibody and found that GR-ir was in the cytoplasm and nucleus of the cells (Fig. 2A). Preabsorption of the antibody with the antigenic xGR peptide greatly reduced immunostaining (Fig. 2B). Exposure to the GR agonist dexamethasone (DEX; $100 \mathrm{nM}$ ) for 1.5 hours caused the GR-ir to concentrate in the nucleus (Fig. 2C,E, untreated; Fig. 2D,F, DEX treated). Exposure to CORT (100 nM) also caused translocation of GR to the nucleus in A6 cells (data not shown). The unique sequence of the antigenic xGR peptide that we used for immunization, the results of the analyses described above, taken together with the results of our IHC analyses on frog brain (discussed below), support that our affinity-purified IgG specifically recognizes frog GR.

\section{Distribution of GR-ir in the brain and pituitary of juvenile $X$. laevis}

IHC analysis showed that GR-ir cells are widely distributed throughout the brain and pituitary of juvenile $X$. laevis. Preabsorption of the anti-xGR IgG with the xGR antigenic peptide eliminated the specific immunosignal in the brain, whereas preabsorption with a mixture of three unrelated peptides (corresponding to three regions of the frog MR) did not alter the staining (Fig. 3). We observed staining of the ependyma throughout the brain, which may be artifactual insofar as it was not eliminated by preabsorption (see Fig. 3B).

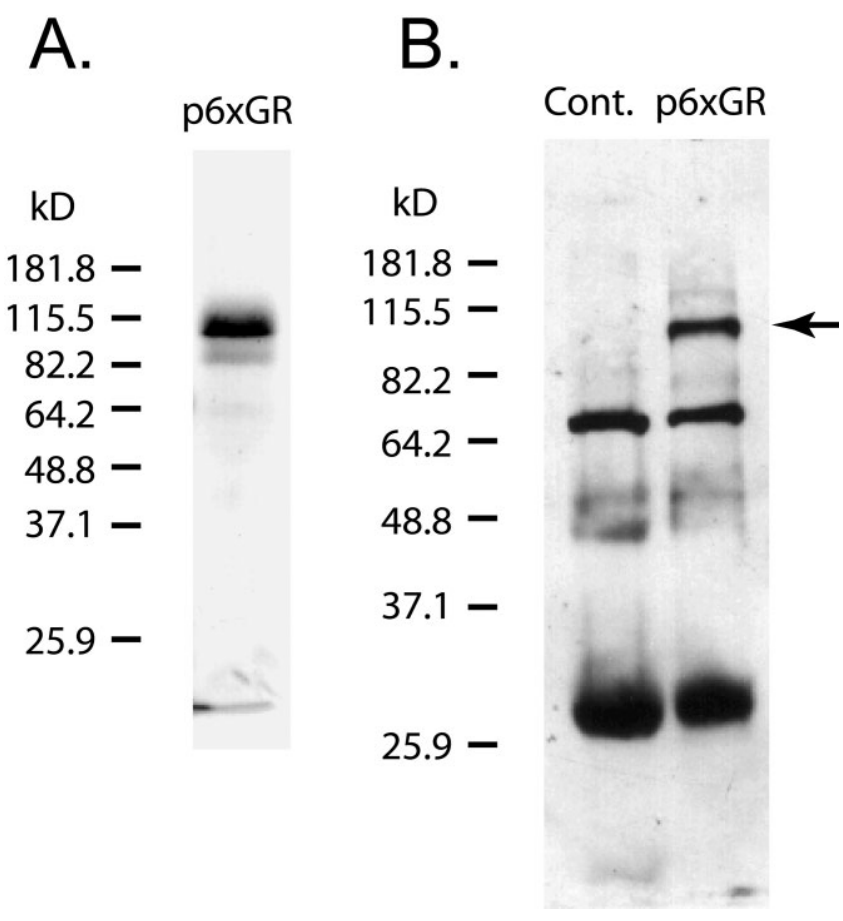

Fig. 1. Affinity-purified antiserum to $X$. laevis GR recognizes fulllength xGR synthesized in vitro. A: A major product of $\sim 96 \mathrm{kD}$ was synthesized in the in vitro transcription/translation reaction using the p6xGR plasmid as template. $\left[{ }^{35} \mathrm{~S}\right]$ methionine + cysteine was included in the in vitro transcription-translation reaction, and the reaction was analyzed by $10 \%$ SDS-PAGE, followed by fluorography. B: A protein of $\sim 96 \mathrm{kD}$ was detected by Western blotting of the in vitro transcription/translation reaction programmed with the $\mathrm{p} 6 \mathrm{xGR}$ vector but not in unprogrammed rabbit reticulocyte lysate. The arrow indicates the $\mathrm{xGR}$ protein band. The two lower MW bands are the rabbit IgG heavy and light chains present in the lysate and recognized by the goat anti-rabbit secondary antibody.

Discrete groups of GR-ir cells were seen in the telencephalon, diencephalon, mesencephalon, and rhombencephalon. In most GR-ir cells in the brain, the immunoreactivity was localized in both the nucleus and the cytoplasm, and in some regions the immunostaining was higher in the cytoplasm than in the nucleus. A schematic representation of the distribution of GR-ir cells in the brain and pituitary gland of $X$. laevis is shown in Figure 4. The detailed distribution of GR-ir cells in the frog brain and pituitary gland is described below.

Telencephalon. The most rostral sites of GR-ir were found in small cells in the lateral pallium and internal granule cell layer of the olfactory bulbs (Figs. 4A,B, 5A,B). In the more caudal portions of the telencephalon, many small GR-ir cells were localized in the dorsal pallium, striatum, and lateral septum. Large GR-ir cells were found in the medial pallium and accumbens (Figs. 4B,C, $5 \mathrm{C}, \mathrm{D})$. The immunoreactivity was seen in both the nucleus and the cytoplasm in most of these GR-ir cells.

Diencephalon. Small GR-ir cells were seen in the lateral, medial, and central amygdala and BNST (Figs. 4D, $5 \mathrm{E}, \mathrm{F})$ The highest density of GR-ir cells was localized in both the parvocellular and the magnocellular divisions of the POA. In rostral regions of the POA, immunostaining was found mostly in the parvocellular cells in the periven- 

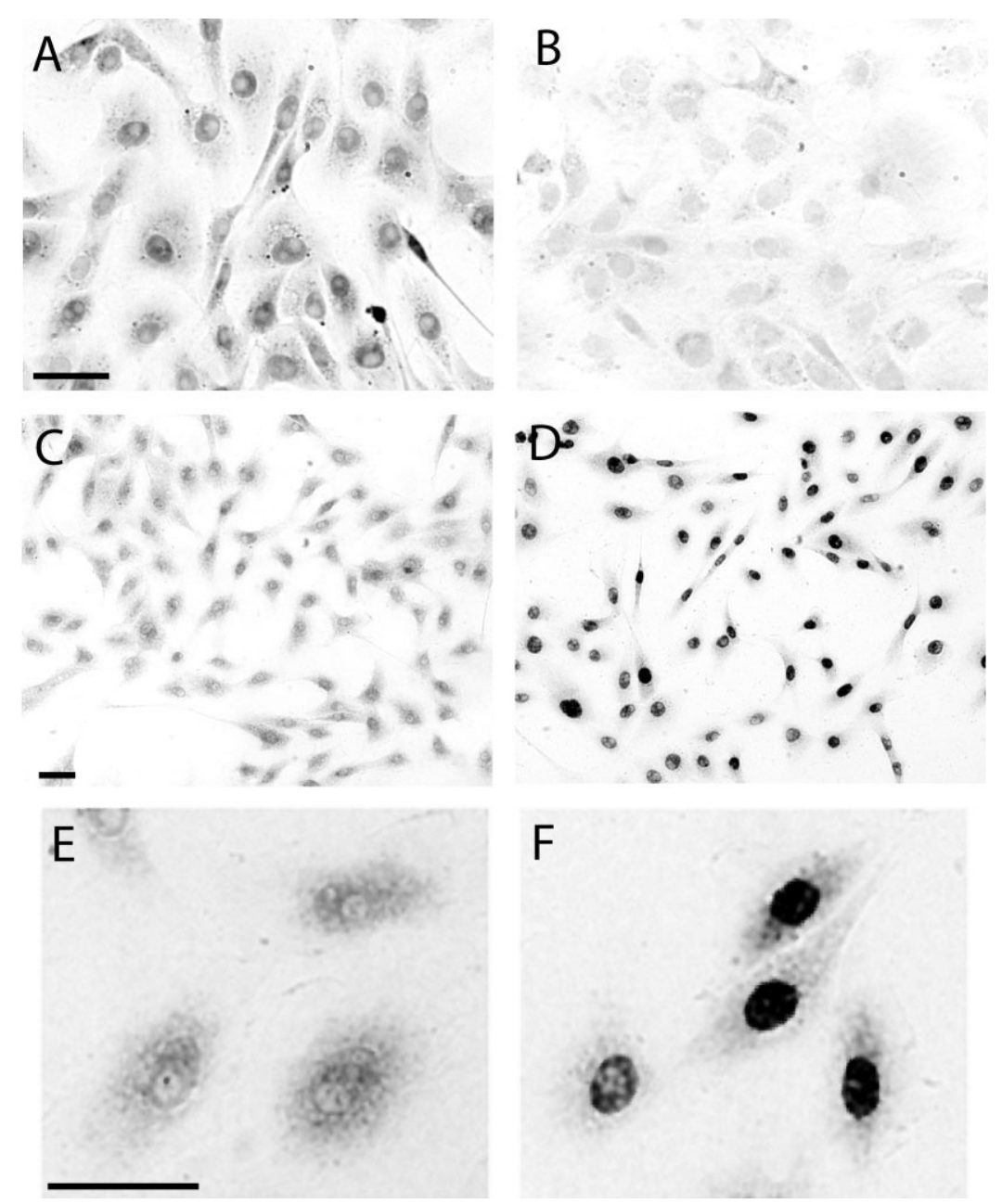

Fig. 2. The affinity-purified anti-xGR IgG recognizes a protein in A6 cells that shows nuclear translocation following treatment with the GR agonist dexamethasone. A6 cells were fixed and immunostained with anti-xGR IgG (A) or anti-xGR IgG preabsorbed with 50 $\mu \mathrm{g} / \mathrm{ml}$ of the antigenic $\mathrm{xGR}$ peptide $(\mathbf{B} ; \times 20$ magnification). $\mathrm{xGR}$ immunoreactivity in A6 cells treated with $(\mathbf{C , E})$ or without $(\mathbf{D}, \mathbf{F})$

tricular zones of the third ventricle (Figs. 4D, 5G). We could not determine whether the GR-ir was nuclear or cytosolic in the parvocellular cells of the POA because of their small size and relatively large nuclei. In more caudal regions of the POA, strong GR-ir was observed in cells in the dorsal magnocellular area (Figs. 4E, 5H). The GR-ir in these cells was found in both the nucleus and the cytoplasm. Several scattered, small GR-ir cells were seen in the hypothalamus and thalamus, including the ventral habenlar, anterior thalamic, ventromedial thalamic, ventrolateral thalamic, posterior thalamic, and ventral hypothalamic nuclei (Figs. 4F,G, 5I). Larger GR-ir cells were found in the suprachiasmatic nucleus (Figs. 4F, 6A). The immunoreactivity was distributed in both the nucleus and the cytoplasm in most of these hypothalamic and thalamic GR-ir cells.

Mesencephalon. Well-organized, small GR-ir cells were also seen in different layers of the optic tectum (Fig. $4 \mathrm{H})$. High levels of GR-ir staining were found in the torus semicircularis, posterior tuberculum regions, and tegmen- dexamethasone for 1.5 hours $(100 \mathrm{nM}) . \mathrm{C}$ and $\mathrm{D}$ are at $\times 10$ magnification, and $\mathrm{E}$ and $\mathrm{F}$ are at $\times 40$ magnification. Scale bars $=100 \mu \mathrm{m}$ in A (applies to A,B); $100 \mu \mathrm{m}$ in C (applies to C,D); $100 \mu \mathrm{m}$ in E (applies to $\mathrm{E}, \mathrm{F}$ ). [Color figure can be viewed in the online issue, which is available at www.interscience.wiley.com.] tal nuclei (Figs. 4H, 6B). The immunoreactivity was found in both the nucleus and the cytoplasm of these GR-ir cells.

Rhombencephalon. Small GR-ir cells were observed in the locus coeruleus (Fig. 4I), and large cells were observed in the cerebellum, especially in the Purkinje cell layer (Fig. 4J; see also Fig. 6C). Small GR-ir cells were found in the raphe nuclei, reticular nuclei, and nuclei of the trigeminal motor nerves (Figs. 4J, 6D). The subcellular distribution of GR-ir in these cells was also both nuclear and cytoplasmic.

Pituitary. Dense GR-ir cells were found in rostral portions of the pars distalis, where the corticotrope cells are located (Fig. 4H, 6E; Campantico et al., 1985). These cells exhibited very strong nuclear GR-ir. Fewer GR-ir cells were seen in the caudal regions of the pars distalis. Weak GR-ir signal was also seen in the pars intermedia layer (Fig. 4H), but we did not identify the cell type (i.e., melanotrope vs. folliculostellate). No GR-ir was observed in the pars nervosa layer or in the median eminence. 

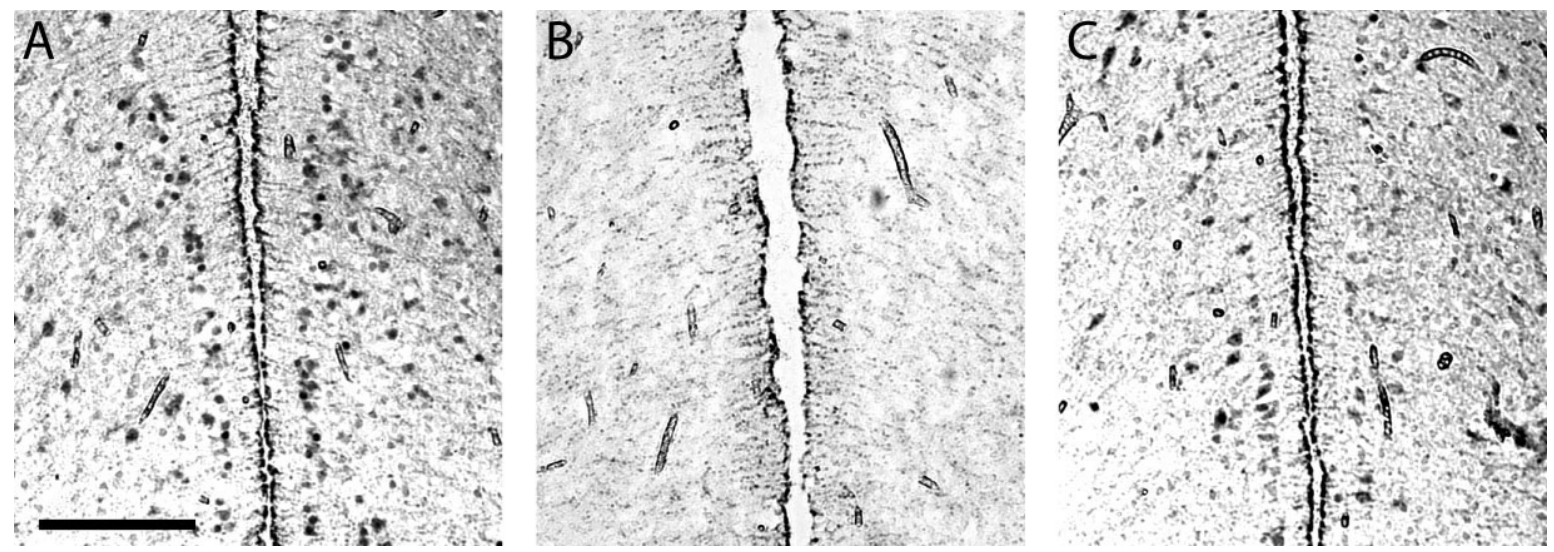

Fig. 3. The anti-xGR IgG specifically stains a subset of cells in the $X$. laevis brain. Shown are photomicrographs of transverse sections through the anterior preoptic area (POA) of a juvenile $X$. laevis. Adjacent sections were immunostained with anti-xGR IgG (A), antixGR IgG preabsorbed with $50 \mu \mathrm{g} / \mathrm{ml}$ of the antigenic $\mathrm{xGR}$ peptide $(\mathbf{B})$,

or anti-xGR IgG preabsorbed with $50 \mu \mathrm{g} / \mathrm{ml}$ of a mixture of three unrelated peptides that corresponded to regions of the frog MR (C). All three images were captured at the same magnification. Scale bar $=120 \mu \mathrm{m}$

\section{Effects of manipulation of plasma corticosteroids on GR-ir in the frog CNS and pituitary gland}

We first conducted an experiment to determine whether the doses of CORT and MTP chosen caused changes in plasma CORT concentrations in juvenile $X$. laevis that were within the physiological range. We treated frogs with vehicle $(0.0005 \%$ ethanol; control), CORT (500 nM), MTP $(110 \mu \mathrm{M})$, or MTP + CORT (50 nM) as described above. Prior to sacrifice and blood collection, we divided the vehicle controls into two groups and exposed one group to shaking/confinement stressor for 6 hours (stressed), whereas the other group (control) was left undisturbed. Treatment with CORT (500 nM) for 4 days increased the plasma CORT concentration to a level similar to that achieved by exposure to shaking/confinement stressor $(P<$ 0.001 , ANOVA; Fig. 7; see also Yao et al., 2004). By contrast, MTP treatment caused the plasma CORT concentration to fall below the detection limit of the RIA (Fig. 7). Exposure to MTP + CORT (50 nM) resulted in plasma CORT concentrations that were not different from control (Fig. 7).

To determine whether circulating GCs can influence GR expression, we analyzed the mean GR-ir signal density in discrete regions of the brain and pituitary gland of juvenile frogs treated with CORT, MTP, or MTP + CORT. In the POA, treatment with CORT decreased mean GR-ir signal density to $\sim 20 \%$ of control $(P<0.001$, ANOVA, Fisher's LSD; Fig. 8B). Treatment with MTP also caused a marked decrease in the mean GR-ir signal density in this brain region to $\sim 60 \%$ of control $(P=0.004$, Fig. $8 \mathrm{C})$, which was reversed by cotreatment with a replacement dose (50 $\mathrm{nM}$ ) of CORT (Fig. 8D).

As in the POA, treatment with CORT decreased mean GR-ir signal density in the MeA (to $\sim 50 \%$ of control, $P=$ 0.009 ), the BNST (to $\sim 60 \%$ of control, $P=0.003$ ), and the $\mathrm{mp}$ (to $\sim 20 \%$ of control, $P<0.001$, Fig. 9). Treatment with MTP also decreased GR-ir in these regions (MeA, to $~ 30 \%$ of control, $P=0.001$; BNST, to $\sim 56 \%$ of control, $P=0.002$; $\mathrm{mp}$, to $\sim 47 \%$ of control, $P<0.001$ ), which could be reversed by cotreatment with a replacement dose of CORT (Fig. 9).
Similar to effects on the brain, treatment with CORT strongly decreased GR-ir signal density in the rostral pars distalis (to $\sim 28 \%$ of control, $P=0.001$; Fig. 9). By contrast, treatment with MTP alone or in combination with a replacement dose of CORT did not alter GR-ir in the pituitary gland (Fig. 9).

\section{Distribution of $G R$ mRNA in frog brain and effects of corticosteroid manipulation}

We detected GR mRNA expression by RTqPCR throughout the adult frog brain (Fig. 10A). There were no significant differences between males and females in any brain region; therefore, we pooled data from both sexes. We found significant differences in $G R$ mRNA expression in different brain regions $(P=0.001$, ANOVA). Higher expression was observed in the forebrain region (telencephalon and preoptic area) and lower expression in the spinal cord.

Manipulation of circulating corticosteroids by CORT or MTP treatment caused significant changes in GR mRNA in the telencephalon/preoptic area $(P=0.004)$. Similar to GR-ir in this and other brain regions, GR mRNA levels were decreased by CORT or MTP treatment by $\sim 30 \%$ and $\sim 35 \%$, respectively, compared with the control (Fig. 10B). Treatment with MTP plus a replacement dose of CORT reversed the effects of MTP on GR mRNA.

\section{DISCUSSION \\ Evolutionary conservation of GC targets in the vertebrate brain and pituitary}

Here we present the first detailed study in a nonmammalian tetrapod of the distribution of GR-ir in the brain and pituitary gland and the regulation of GR by circulating corticosteroids. We found GR-ir cells distributed throughout the brain, from the olfactory bulbs to the brainstem. The wide distribution of GR-ir in the CNS is consistent with findings in mammals, a bird, and several teleost fishes; expression of GR in all regions of the frog brain mentioned above has been reported for homologous brain regions of the rat (Ahima and Harlan, 1990; Mori- 
A

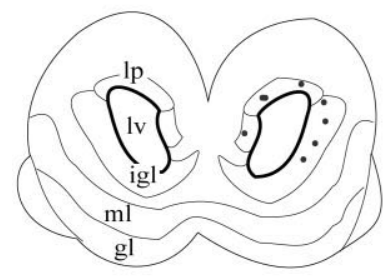

B

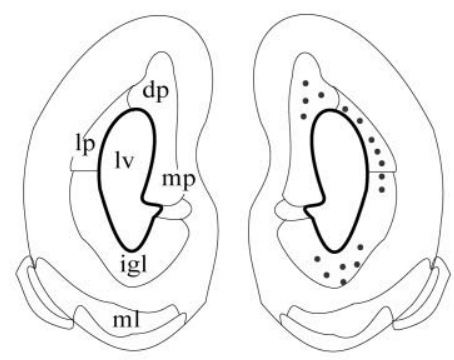

$\mathrm{C}$

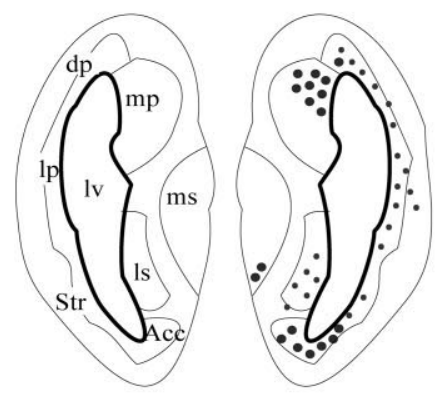

$\mathrm{D}$

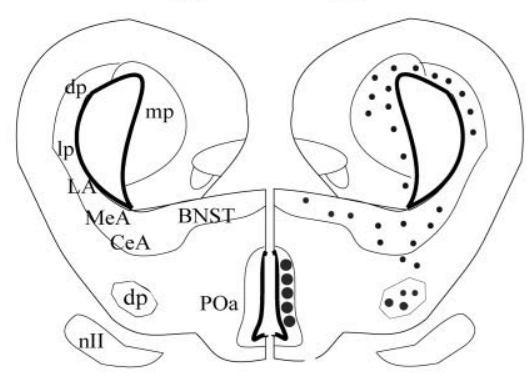

$\mathrm{E}$

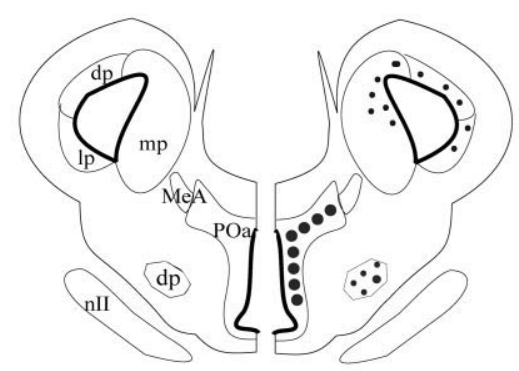

Fig. 4. A-J: Schematic coronal illustration of glucocorticoid receptor (GR) immunoreactivity (-ir) distribution in the brain of juvenile $X$. laevis. The drawing at the top of the figure shows a dorsal view of the $X$. laevis brain. Letters correspond to the rostrocaudal location of sections as depicted in the whole-brain drawing. Large circles repre-
$\mathrm{F}$

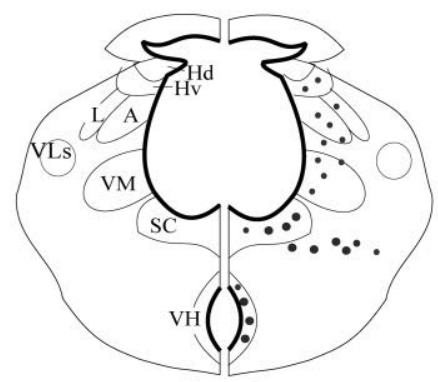

G

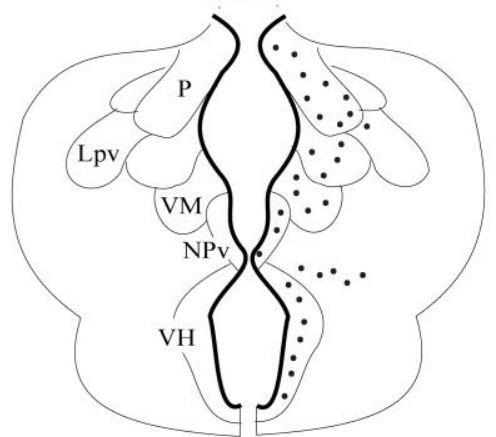

$\mathrm{H}$
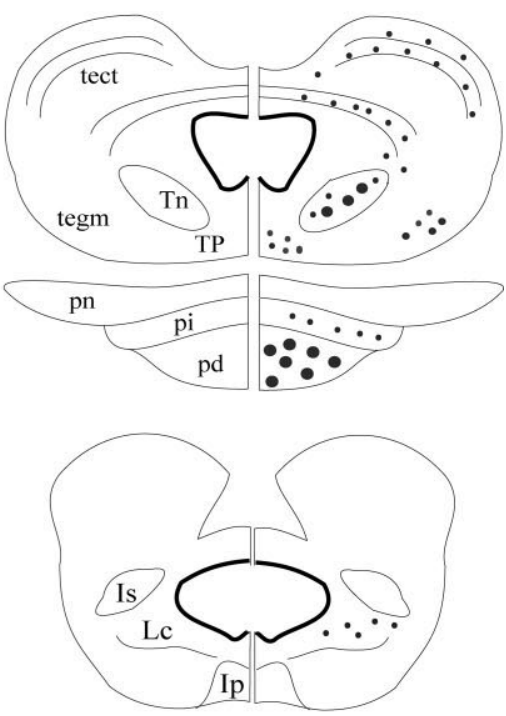

I

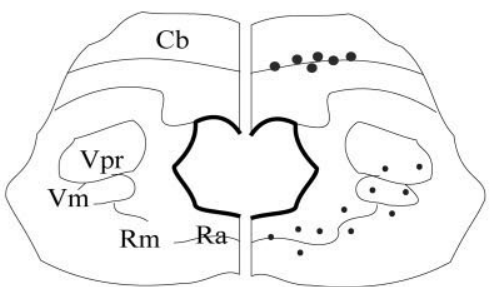

sent large cells that exhibited robust GR-ir, and small circles represent smaller GR-ir cells. The anatomical drawings are from Tuinhof et al. (1998), with modifications of basal ganglia subdivisions according to Marín et al. (1998). 

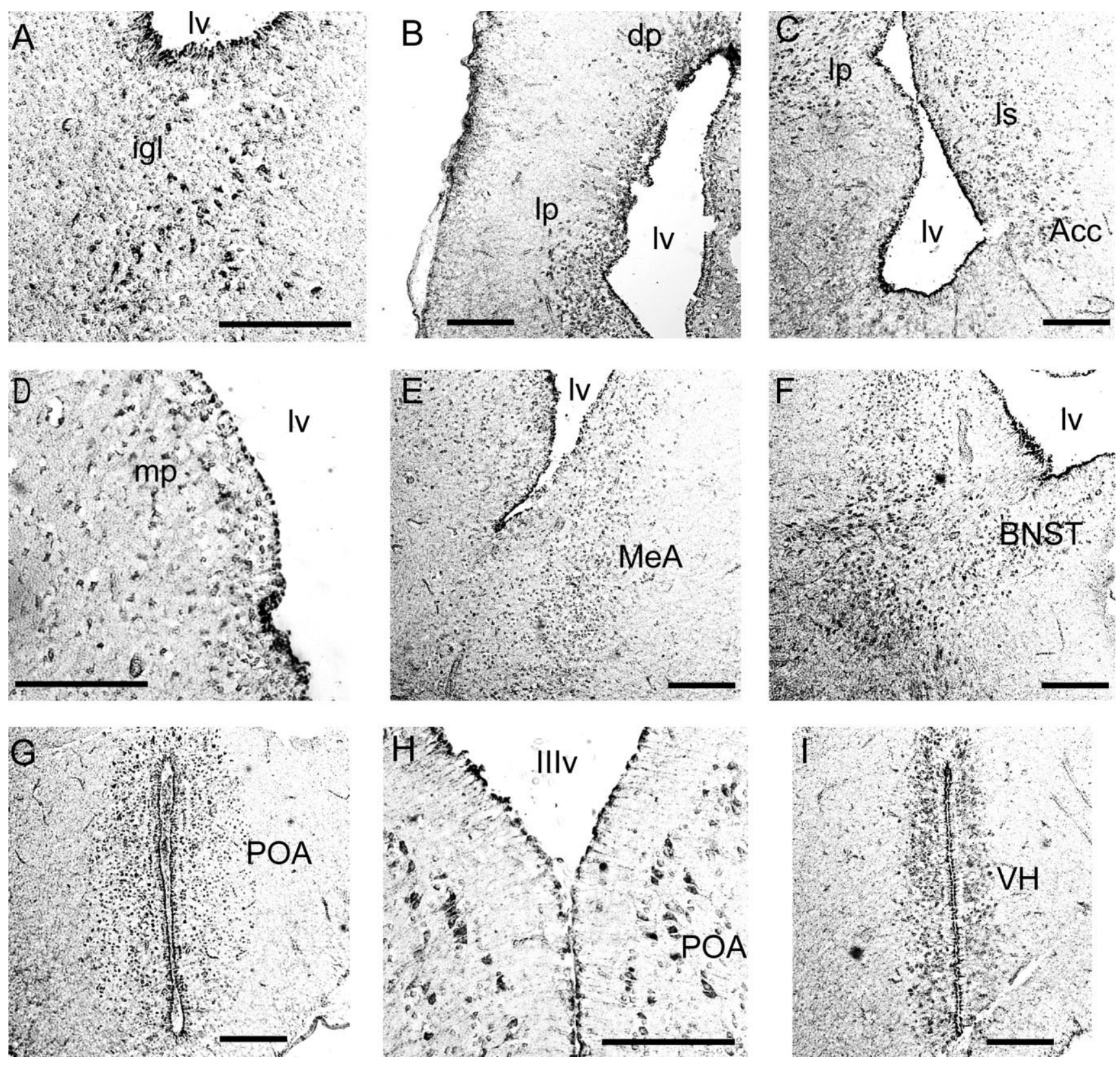

Fig. 5. Photomicrographs of transverse sections through the forebrain and part of the midbrain of juvenile $X$. laevis showing the distribution of glucocorticoid receptor (GR)-immunoreactive (-ir) cells. A: Internal granule cell layer of the olfactory bulb (igl). B: Dorsal pallium (dp) and lateral pallium (lp). C: Nucleus accumbens (Acc) and lateral septum (ls). D: Medial pallium (mp). E: Medial amygdala (MeA) . F: Bed nucleus of the stria terminalis (BNST). G: Anterior preoptic area (POA). H: Posterior preoptic area (POA). I: Ventral hypothalamic nucleus $(\mathrm{VH})$. lv, Lateral ventricle, IIIv, third ventricle. Scale bars $=120 \mu \mathrm{m}$ moto et al., 1996) and Japanese quail (Kovács et al., 1989), and most of these structures in fishes (Carruth et al., 2000; Teitsma et al., 1998). The strong GR-ir signal in forebrain structures of the frog is consistent with our RTqPCR analysis, which showed that $G R$ mRNA levels were highest in the forebrain (telencephalon and preoptic area) compared with more caudal regions (e.g., the optic tectum, hindbrain, and spinal cord). Our IHC analyses were conducted on sexually immature juvenile frogs, and, although we could not conduct a thorough analysis of possible sex differences in GR expression, we found no such differences in GR mRNA levels throughout the sexually mature adult frog brain.

\section{The GR is expressed in hypophysiotropic brain nuclei and the pituitary gland}

We found high GR-ir density in the parvocellular division of the POA in the frog brain, similar to that observed in the rat and in fishes (Carruth et al., 2000; Teitsma et al., 1998). Cells in this region express a number of neu- 

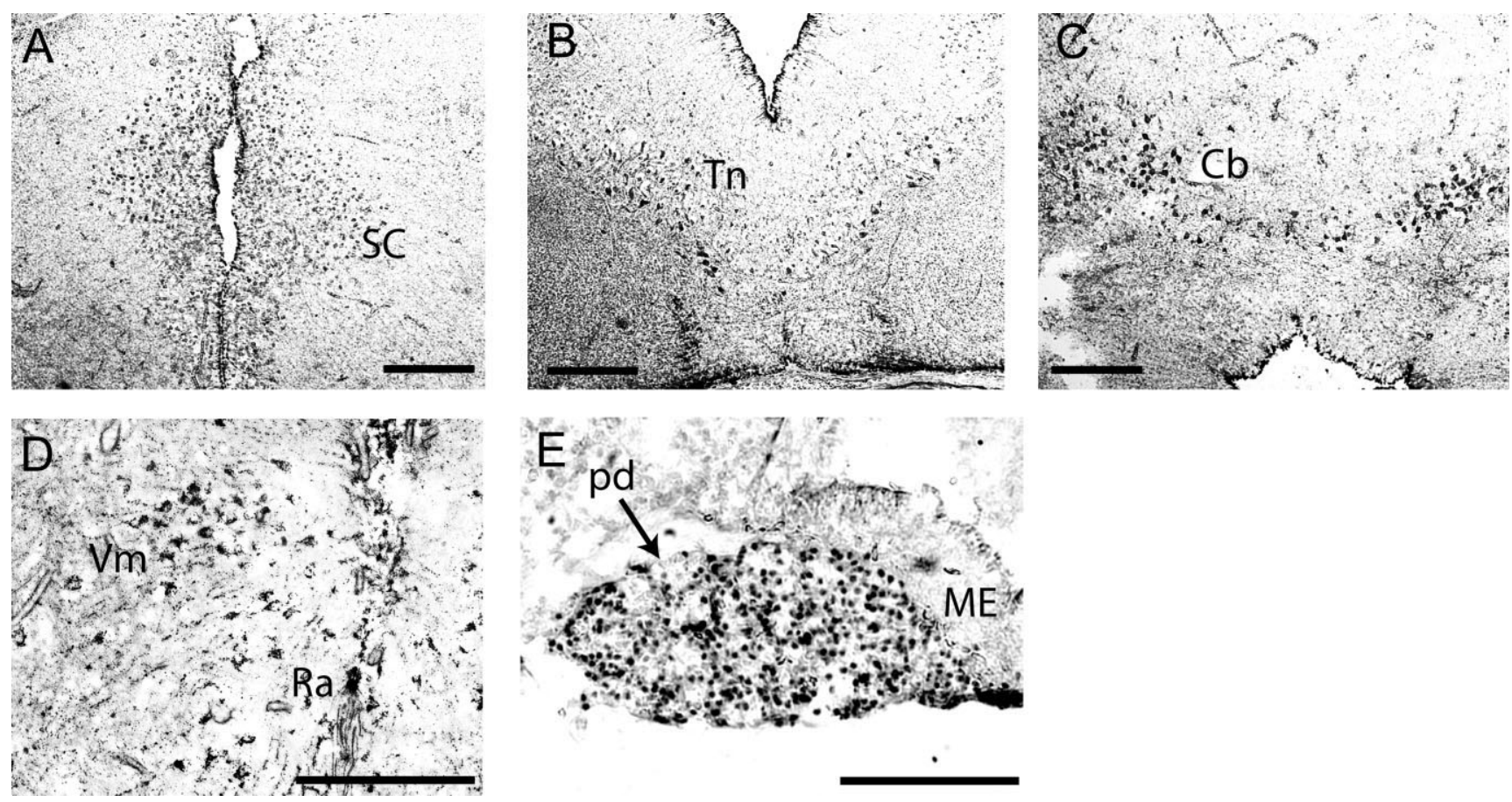

Fig. 6. Photomicrographs of transverse sections through the midbrain, hindbrain, and pituitary gland of juvenile $X$. laevis showing the distribution of glucocorticoid receptor (GR)-immunoreactive cells. A: Suprachiasmatic nucleus (SC). B: Tegmental nuclei (Tn). C: Cer-

ebellum $(\mathrm{Cb})$. D: Motor nucleus of the trigeminal nerve $(\mathrm{Vm})$ and raphe nucleus $(\mathrm{Ra})$. E: Pars distalis of the anterior pituitary gland (pd with arrow; ME, median eminence). Scale bars $=120 \mu \mathrm{m}$. ropeptides, including CRF (Bidaud et al., 2004; Calle et al., 2006; Daniello et al., 1996; DiMatteo et al., 1996; González et al., 1995; Yao et al., 2004). GCs cause negative feedback on neurosecretory CRF neurons in the frog similar to that in mammals and fishes (Yao et al., 2008; for review see Yao et al., 2007). The high expression of GR in this region suggests that GCs exert direct actions on these cells, which is further supported by our finding that CRF and GR colocalize in cells of the frog POA (Yao et al., 2008).

A significant difference between GR-ir distribution in the frog and the bird and mammal is that we found a high density of GR-ir in the magnocellular division of the frog POA, whereas no GR-ir was detected in the magnocellular division of the PVN in intact rat or Japanese quail (Kovács et al., 1989). Cells in this region express urocortin I and arginine vasotocin (Acher, 1996; Calle et al., 2005). Strong GR-ir in these cells was also found in rainbow trout and kokanee salmon (Carruth et al., 2000; Teitsma et al., 1998). The finding of high basal GR expression in the magnocellular POA in the frog and in fishes but not in the homologous regions of a bird or mammals could be related to the aquatic vs. terrestrial life histories of these species. However, it is noteworthy that, although the rat has undetectable GR in the magnocellular PVN neurons in the basal state, exposure to osmotic stress induced GR expression in AVP neurons located in this region (Berghorn et al., 1995). Also, studies in transfected cells found direct inhibition of AVP gene promoter activity by dexamethasone (Iwasaki et al., 1997).

We found strong GR-ir in cell nuclei of the frog rostral pars distalis. A high density of GR-ir in this tissue was

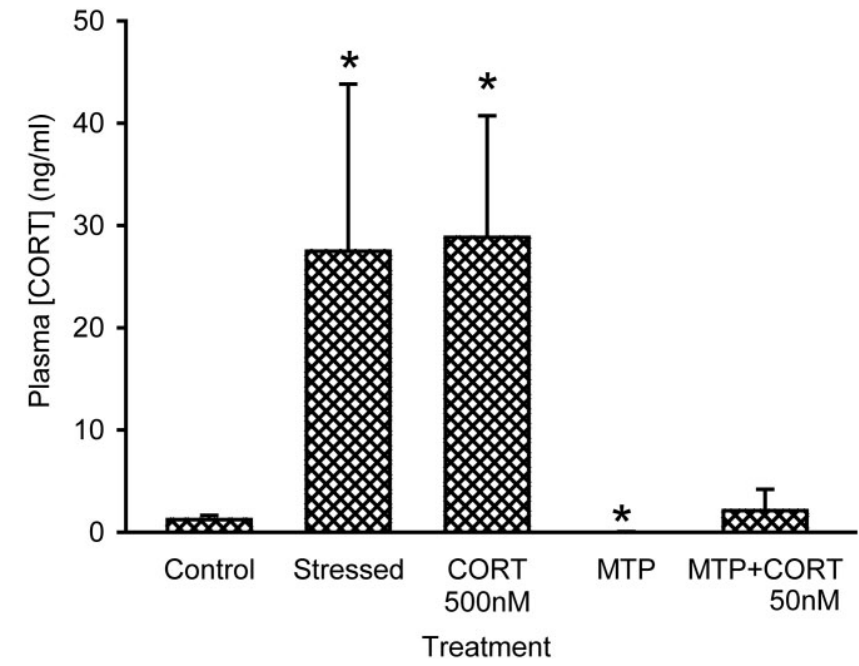

Fig. 7. Plasma corticosterone concentrations in $X$. laevis juveniles following pharmacological treatments and exposure to shaking/ confinement stressor. Juvenile frogs were reared in water containing vehicle $(0.0005 \%$ ethanol; control and stressed) for 4 days, corticosterone (CORT; $500 \mathrm{nM}$ ) for 4 days, metyrapone (MTP; $110 \mu \mathrm{M}$ ) for 5 days, or MTP for 1 day followed by MTP + CORT (50 nM) for 4 days (MTP CORT $50 \mathrm{nM}$ ). During the 4-day treatment period, all groups were exposed to $0.0005 \%$ ethanol. The "stressed" group was exposed to 6 hours of shaking/confinement stressor before sacrifice; animals in the other treatments were left undisturbed, and all animals were killed in the afternoon of the same day. Data presented are the mean \pm SEM. Significant differences from control are indicated $(n=$ 5-6/treatment; $* P<0.05$, ANOVA). 

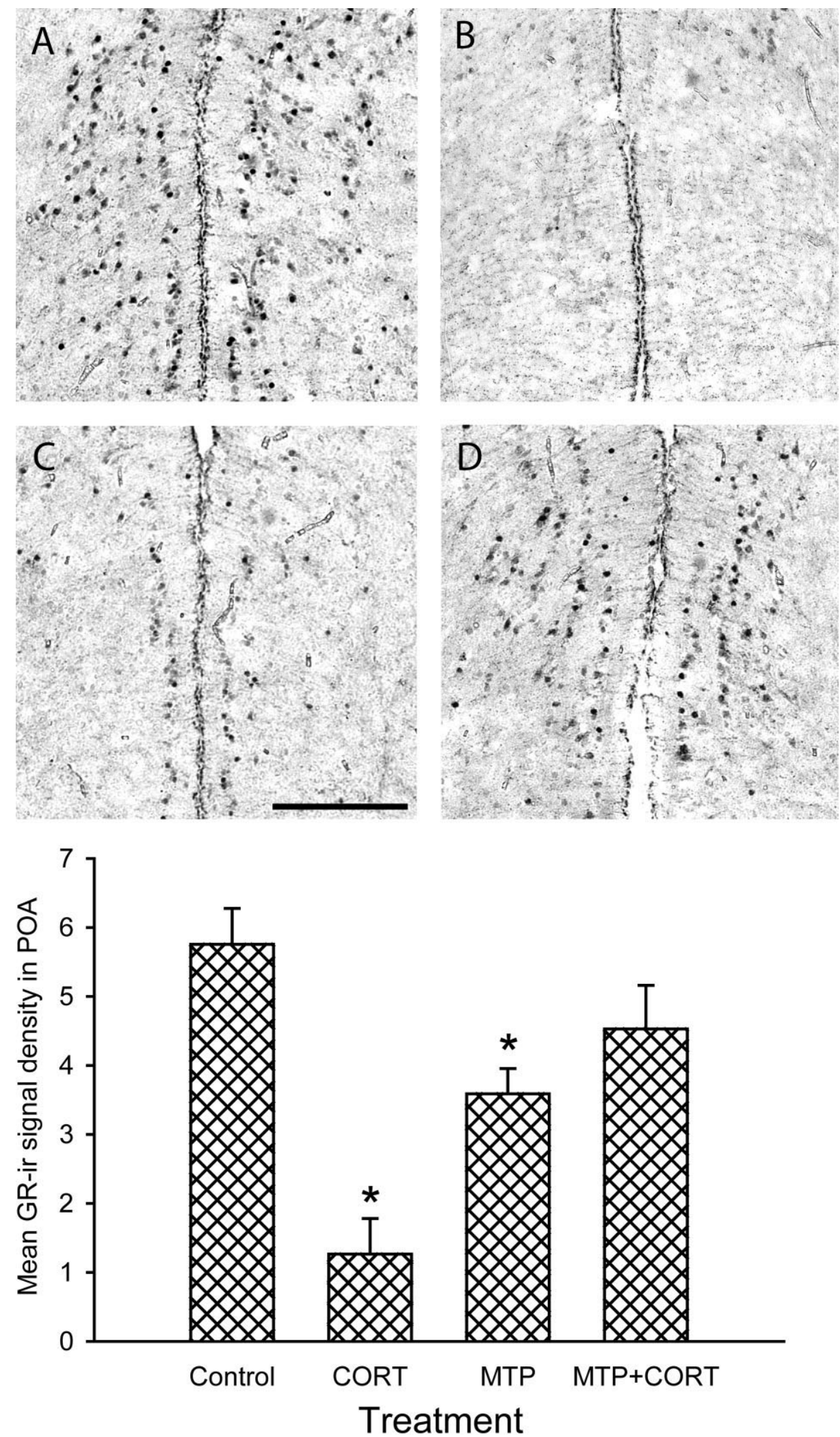

Fig. 8. Effects of changes in plasma corticosteroid concentration on glucocorticoid receptor (GR) immunoreactivity (-ir) in the anterior preoptic area (POA) of juvenile $X$. laevis. A: The photomicrographs are of representative transverse sections in the same anatomical plane of the POA; vehicle control (B; $0.0005 \%$ ethanol), corticosterone $(\mathbf{C}$ CORT; $500 \mathrm{nM}$ for 4 days), metyrapone (D; MTP; $110 \mu \mathrm{M}$ for 5 days),
MTP + CORT $(110 \mu \mathrm{M}$ MTP for 1 day followed by MTP $+50 \mathrm{nM}$ CORT for 4 days). The graph shows the densitometric analysis of GR-ir in the POA following hormone or drug treatments (treatments as described above). Bars represent the mean \pm SEM. Significant differences from the control are indicated $(\mathrm{n}=5-6 /$ treatment, $* P<$ 0.05 ; ANOVA). Scale bar $=120 \mu \mathrm{m}$. 

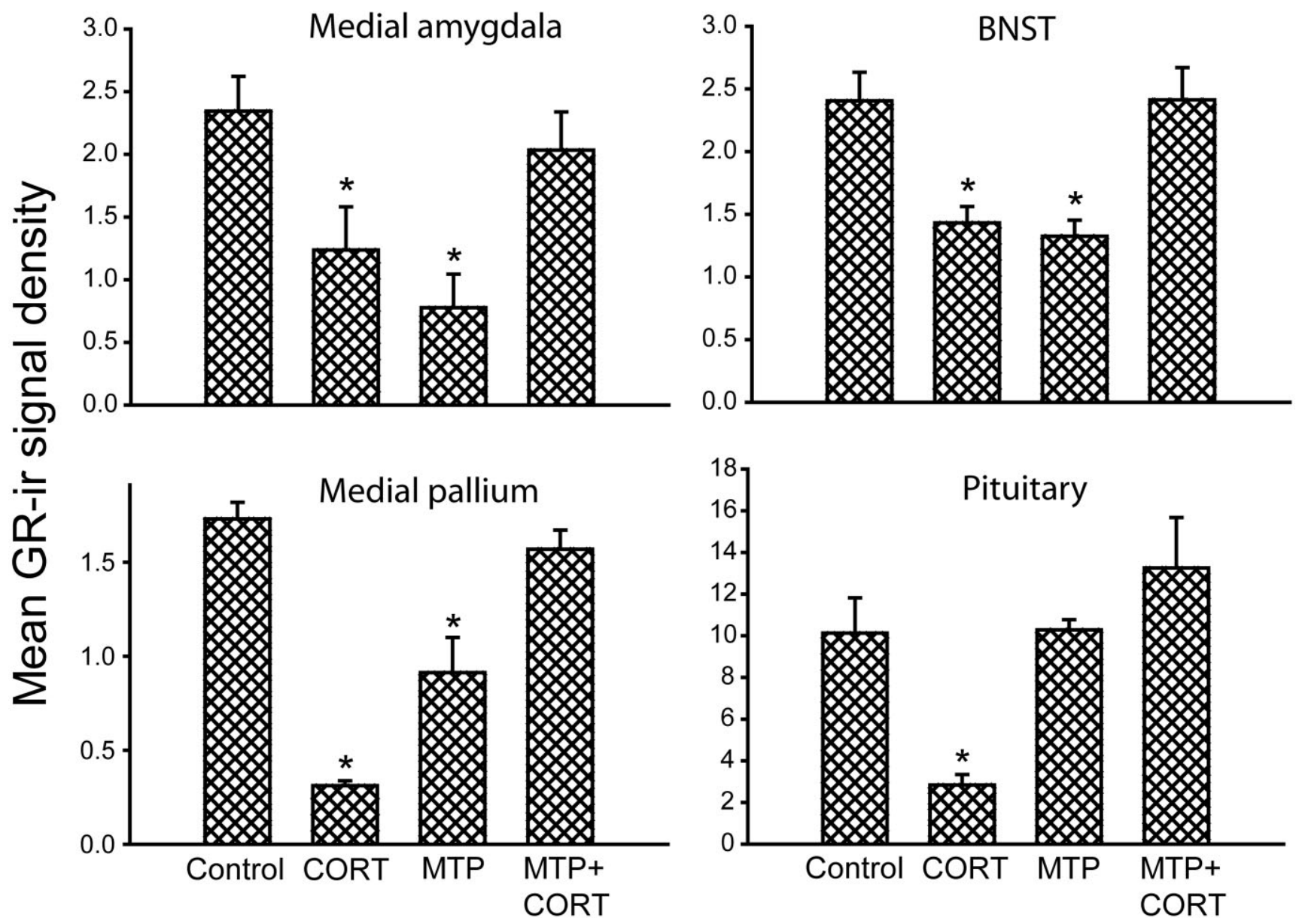

Fig. 9. Effects of changes in plasma corticosteroid concentration on glucocorticoid receptor (GR) immunoreactivity (-ir) in the medial amygdala, bed nucleus of the stria terminalis (BNST), medial pallium, and rostral pars distalis of the anterior pituitary of juvenile $X$.

laevis. Treatments are described in the legend to Figure 8. Bars represent the mean GR-ir density (see Materials and Methods) \pm SEM. Significant differences from the control are indicated $(\mathrm{n}=$ 5-6/treatment; $* P<0.05$, ANOVA).

also reported for mammals and fishes, and GCs are well known to influence anterior pituitary hormone biosynthesis and secretion (Ahima and Harlan, 1990; Carruth et al., 2000; Herman et al., 2003; Kononen et al., 1993; Morimoto et al., 1996; Ozawa et al., 1999; Teitsma et al., 1998). We also found weak GR-ir staining in the intermediate lobe of the frog pituitary gland. GR-ir was not detected in this region of the pituitary of intact rat or rainbow trout, although $G R$ mRNA and GC binding activity have been reported here in rat (Ahima and Harlan, 1990; Morimoto et al., 1996; Ozawa et al., 1999; Sheppard et al., 1993; Teitsma et al., 1998). In $X$. laevis, the neurointermediate lobe expresses proopiomelanocortin (POMC), which is processed to $\alpha$-melanocyte-stimulating hormone ( $\alpha \mathrm{MSH})$; $\alpha \mathrm{MSH}$ plays an important role in background adaptation in the frog (Dotman et al., 1996; Loh et al., 1985; Tuinhof et al., 1998). The expression of GR suggests that POMC gene expression, and thus $\alpha \mathrm{MSH}$, could be subject to regulation by circulating GCs. Our finding that GR-ir is not present in the posterior pituitary (neural lobe) of the frog is in agreement with studies in rainbow trout (Teitsma et al., 1998), although GR-ir has been found in the rat neural lobe (Kononen et al., 1993; Ozawa et al., 1999).

\section{Expression of GR in the frog limbic system suggests a phylogenetically ancient role for these structures in regulation of the HPA axis}

We observed high GR-ir density in limbic structures of the frog brain. The expression of $G R$ mRNA and protein in limbic structures is well documented in mammals (Ahima and Harlan, 1990; Morimoto et al., 1996). In the mammalian hippocampus, the CA1 and CA2 pyramidal cell layers and the dentate gyrus all express high levels of $G R$ mRNA and GR-ir (Ahima and Harlan, 1990; Morimoto et al., 1996). Strong expression of $G R$ mRNA and immunoreactivity were also seen in all subfields of the amygdala and BNST (Ahima and Harlan, 1990; Morimoto et al., 1996).

The amphibian and fish homologs of the mammalian hippocampus (medial pallium) are much less differentiated compared with mammals. Also, although the subfields of the amygdala are biochemically distinct in frogs and fishes, they are more difficult to distinguish morphologically than those of mammals. Nonetheless, we observed dense GR-ir cells in the frog $\mathrm{mp}$, the MeA, and the BNST. Similar GR distribution was observed in fishes 
A.

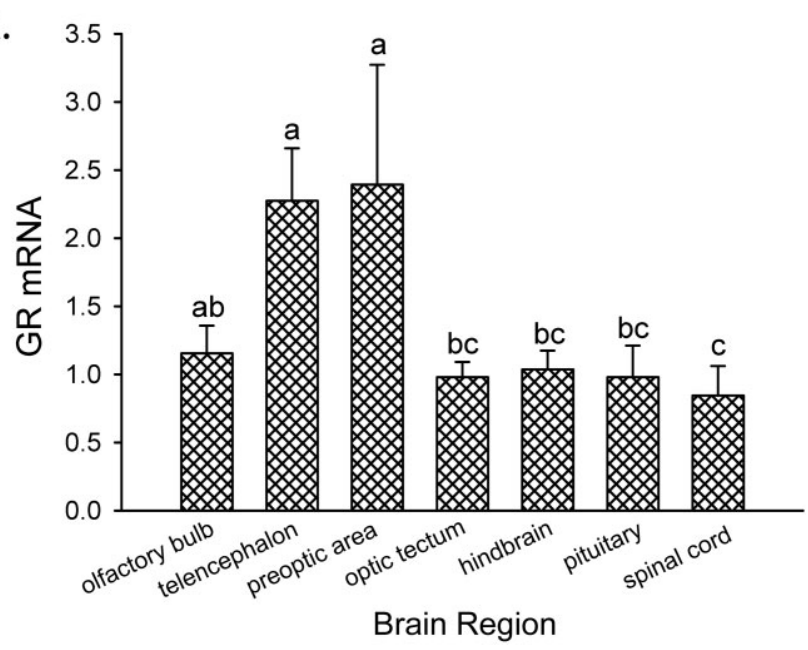

B.

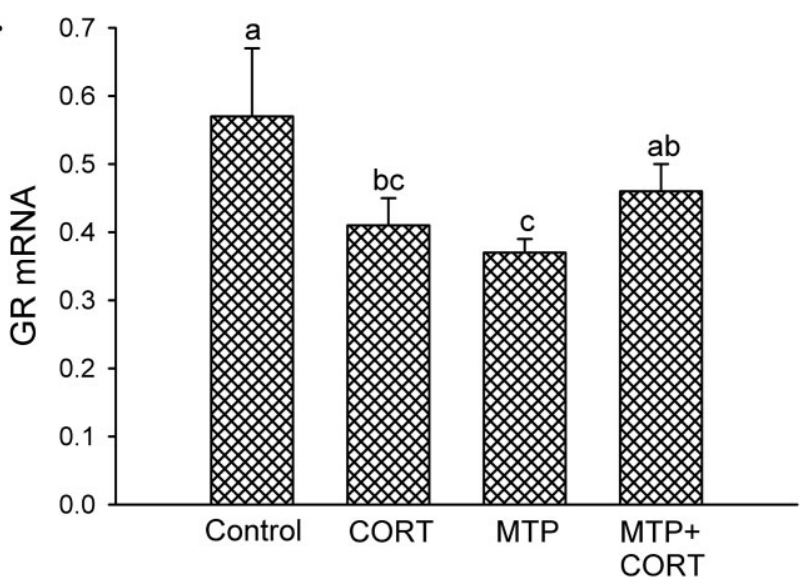

Fig. 10. Expression of $G R$ mRNA in frog brain as analyzed by real-time quantitative PCR (RTqPCR). A: Distribution of GR mRNA in adult frog brain. Brain regions were microdissected from five male and five female adult $X$. laevis. There were no sex differences in $G R$ mRNA expression, so we pooled the data $(\mathrm{n}=8-10$ per brain region). B: Effects of manipulation of circulating corticosteroids on mRNA expression in the telencephalon/preoptic area of juvenile $X$. laevis. Frogs were treated as described in the legend to Figure 8. Total RNA was extracted and gene expression analyzed by RTqPCR. A relative quantitation method was used, and GR mRNA was normalized to the expression of the housekeeping gene $r p L 8$; therefore, the data are presented as arbitrary units. Bars represent the mean \pm SEM. Letters indicate significant differences among brain regions or treatment groups $(P<0.05$, Fisher's LSD multiple-comparisons test).

(Carruth et al., 2000; Teitsma et al., 1998). The only study to our knowledge on GR-ir distribution in the bird brain did not find it in the hippocampus or the archistriatum, whereas GR-ir was observed in the lateral septum (Kovács et al., 1989). The investigators did not report whether they found GR-ir in other limbic structures (e.g., the amygdala or BNST) in the bird brain. Conserved patterns of GR expression in limbic structures in fishes, frog, and mammals suggest that the regulation of these regions by GCs may be phylogenetically ancient and evolutionarily conserved. GCs can negatively regulate the activity of PVN $\mathrm{CRF}$ neurons in mammals indirectly via a descending inhibitory pathway originating in the hippocampus (for review see Yao et al., 2007). By contrast, GCs induced CRF expression in the amygdala and BNST of mammals (Makino et al., 1994) and the frog (Yao et al., 2008). Our findings of GR expression in the homologous regions of the frog brain suggest that these structures could play similar roles (e.g., cognition, fear responses) and that GCs influence their structure and function in frogs as they do in mammals.

\section{GCs regulate GR expression in the frog brain}

Autoregulation of GR expression by GCs has been described in mammals, and we found similar actions in the frog, suggesting that this mode of regulation is phylogenetically ancient. Treatment with CORT decreased GR-ir in the POA, MeA, BNST, mp, and anterior pituitary of the frog. CORT treatment also decreased GR mRNA in the frog telencephalon/preoptic area. In the rat, administration of GCs for days to weeks decreased GR protein and mRNA throughout the brain (Chao et al., 1998; Ghosh et al., 2000; Han et al., 2007; Holmes et al., 1995; HüginFlores et al., 2004; Reul et al., 1989; Sapolsky et al., 1984; Spencer et al., 2000). In tissue culture studies, GCs decreased expression of $G R$ mRNA and protein or activity of the $G R$ gene promoter in transfected cells (Bellingham et al., 1992; Burnstein et al., 1991; Dong et al., 1988; Meyer and Schmidt, 1995; Okret et al., 1986; Silva et al., 1994; Vedeckis et al., 1989). Different mechanisms for the downregulation of GR expression by GCs have been proposed, including inhibition of transcription (Dong et al., 1988; Okret et al., 1991; Rosewicz et al., 1988), posttranscriptional regulation (decreased mRNA stability or translatability; Burnstein et al., 1991; Meyer and Schmidt, 1995; Okret et al., 1986; Vedeckis et al., 1989), and posttranslational regulation (decreased protein stability and/or increased protein degradation; Dong et al., 1988; Okret et al., 1991; Webster et al., 1997).

If GCs negatively regulate GR expression, then one would predict that their removal by surgical or chemical adrenalectomy would elevate GR expression. Such an effect has been reported in rats, where short-term adrenalectomy (1-5 days) increased total GR protein in the hippocampus, hypothalamus/PVN, and cortex as measured by Western blotting (Kalman and Spencer, 2002; O'donnell et al., 1995; Spencer et al., 2000). Short-term (within 1 week) adrenalectomy also increased $G R$ mRNA in the hippocampus, which was reversed by GC supplementation, whereas GR mRNA in the PVN was increased or unaffected by short-term adrenalectomy (Chao et al., 1998; Han et al., 2007; Holmes et al., 1995; Hügin-Flores et al., 2004; Reul et al., 1989).

However, we found in the frog that treatment with the corticosteroid synthesis inhibitor MTP for 5 days decreased GR-ir in POA, MeA, BNST, and mp. The decrease caused by MTP was reversed by cotreatment with a replacement dose of CORT. The changes in GR-ir in the brain with MTP were paralleled by changes in $G R$ mRNA. The GR-ir in the anterior pituitary was unaffected by MTP, which suggests that the regulation of GR expression is cell type dependent and also argues against a nonspecific toxicity of the MTP. In the rat, by contrast to the short-term ( $<1$ week) effects of ADX (discussed above), 1 week of ADX produced a marked decrease in GR-ir in several brain areas (Hu et al., 1997b; Rosenfeld et al., 1988; Visser et al., 1996), and longer-term $\operatorname{ADX}$ ( $\geq 1$ week) 
resulted in the loss of detectable GR-ir throughout the brain (Han et al., 2005; Hu et al., 1997a; Visser et al., 1996). Taken together, our findings in the frog and those in the rat suggest that, although elevated GCs can negatively regulate GR expression, a basal GC level may be required for maintaining GR expression over the longer term.

Autoregulation of GR by circulating GCs is hypothesized to be an important mechanism for regulating the responsiveness of the HPA axis during chronic stress. In rats exposed to repeated or chronic stressors, GR mRNA expression was down-regulated in the hippocampus, frontparietal cortex, PVN, and LC (Gomez et al., 1996; Herman et al., 1995; Makino et al., 1995, 2002b; Nishimura et al., 2004). Decreases in $G R$ expression in these brain regions during chronic stress may indicate a reduced inhibition of the HPA activity by elevated circulating GCs, which could contribute to maintaining the sensitivity of the tissue to GCs and sustaining the responsiveness of the HPA axis to further stimulation (Makino et al., 1995, 2002a).

In conclusion, our results support the idea that the general patterns of GR expression in the CNS and pituitary gland are highly conserved among vertebrates. Thus GR is likely to play roles in mediating the actions of corticosteroids on the frog brain similar to those in mammals, suggesting that the basic regulatory pathways of the neuroendocrine stress axis arose early in vertebrate evolution and have been maintained by natural selection. Expression of GR-ir in the frog brain areas involved in the stress response (POA, mp, MeA, BNST) and the anterior pituitary is regulated by circulating corticosteroids. These findings suggest that autoregulation of GR in specific brain regions and pituitary may be an evolutionarily conserved mechanism for modulating the responsiveness of the stress axis in vertebrates.

\section{ACKNOWLEDGMENTS}

We are very grateful to Dr. Olivier Destree for providing the frog GR expression plasmid and Dr. Jamshed Tata for providing the XTC-2 and A6 cells. This work utilized the Protein Structure Core of the Michigan Diabetes Research Training Center funded by NIH5P60 DK20572 from the National Institute of Diabetes and Digestive Kidney Disease.

\section{LITERATURE CITED}

Acher R. 1996. Molecular evolution of fish neurohypophysial hormones: neutral and selective evolutionary mechanisms. Gen Comp Endocrinol 102:157-172.

Ahima RS, Harlan RE. 1990. Charting of type II glucocorticoid receptorlike immunoreactivity in the rat central nervous system. Neuroscience 39:579-604.

Bamberger CM, Schulte HM, Chrousos GP. 1996. Molecular determinants of glucocorticoid receptor function and tissue sensitivity to glucocorticoids. Endocrine Rev 17:245-261.

Bellingham DL, Sar M, Cidlowski JA. 1992. Ligand-dependent downregulation of stably transfected human glucocorticoid receptors is associated with the loss of functional glucocorticoid responsiveness. Mol Endocrinol 6:2090-2102.

Berghorn KA, Knapp LT, Hoffman GE, Sherman TG. 1995. Induction of glucocorticoid receptor expression in hypothalamic magnocellular vasopressin neurons during chronic hypoosmolality. Endocrinology 136: $804-807$.

Bidaud I, Galas L, Bulant M, Jenks BG, Ouwens D, Jegou S, Ladram A, Roubos EW, Tonon MC, Nicolas P, et al. 2004. Distribution of the
mRNAs encoding the thyrotropin-releasing hormone (TRH) precursor and three TRH receptors in the brain and pituitary of Xenopus laevis: effect of background color adaptation on $\mathrm{TRH}$ and $\mathrm{TRH}$ receptor gene expression. J Comp Neurol 477:11-28.

Bridgham JT, Carroll SM, Thornton JW. 2006. Evolution of hormonereceptor complexity by molecular exploitation. Science 312:97-101.

Burnstein KL, Bellingham DL, Jewell CM, Powelloliver FE, Cidlowski JA. 1991. Autoregulation of glucocorticoid receptor gene expression. Steroids 56:52-58.

Calle M, Corstens GJH, Wang LC, Kozicz T, Denver RJ, Barendregt HP, Roubos EW. 2005. Evidence that urocortin I acts as a neurohormone to stimulate alpha-MSH release in the toad Xenopus laevis. Brain Res 1040:14-28.

Calle M, Jenks BG, Corstens GJH, Veening JG, Barendregt HP, Roubos EW. 2006. Localisation and physiological regulation of corticotrophinreleasing factor receptor $1 \mathrm{mRNA}$ in the Xenopus laevis brain and pituitary gland. J Neuroendocrinol 18:797-805.

Campantico E, Guastalla A, Patriarca E. 1985. Identification by immunofluorescence of ACTH-producing cells in the pituitary gland of the tree frog Hyla arborea. General and Comparative Endocrinology 59(2):192198.

Carruth LL, Jones RE, Norris DO. 2000. Cell density and intracellular translocation of glucocorticoid receptor-immunoreactive neurons in the kokanee salmon (Oncorhynchus nerka kennerlyi) brain, with an emphaisis on the olfactory system. Gen Comp Endocrinol 117:66-76.

Chao HM, Ma LY, McEwen BS, Sakai RR. 1998. Regulation of glucocorticoid receptor and mineralocorticoid receptor messenger ribonucleic acids by selective agonists in the rat hippocampus. Endocrinology 139: $1810-1814$.

Chrousos GP. 1998. Stressors, stress, and neuroendocrine integration of the adaptive response-the 1997 Hans Selye Memorial Lecture. Ann N Y Acad Sci 851:311-335.

Chrousos GP, Gold PW. 1992. The concepts of stress and stress system disorders-Overview of physical and behavioral homeostasis. JAMA 267:1244-1252.

Claire M, Machard B, Lombes M, Oblin ME, Bonvalet JP. 1989. Aldoserone receptors in A6 cells: physicochemiscal characterization and autoradiographic study. Am J Physiol 257:C875-C884.

Daniello B, Vallarino M, Pinelli C, Fiorentino M, Rastogi RK. 1996. Neuropeptide Y: localization in the brain and pituitary of the developing frog (Rana esculenta). Cell Tissue Res 285:253-259.

De Kloet ER, Vreugdenhil E, Oitzl MS, Joels M. 1998. Brain corticosteroid receptor balance in health and disease. Endocrine Rev 19:269-301.

DiMatteo L, Vallarino M, Pierantoni R. 1996. Localization of GnRH molecular forms in the brain, pituitary, and testis of the frog, Rana esculenta. J Exp Zool 274:33-40.

Dong Y, Poellinger L, Gustafsson JA, Okret S. 1988. Regulation of glucocorticoid receptor expression: Evidence for transcriptional and posttranslational mechanisms. Mol Endocrinol 2:1256-1264.

Dotman CH, Cruijsen P, Jenks BG, Roubos EW. 1996. Differential action of secretoinhibitors on proopiomelanocortin biosynthesis in the intermediate pituitary of Xenopus laevis. Endocrinology 137:4551-4557.

Ducouret B, Tujague M, Ashraf J, Mouchel N, Servel N, Valotaire Y, Thompson EB. 1995. Cloning of a teleost fish glucocorticoid receptor shows that it contains a deoxyribonucleic acid binding domain different from that of mammals. Endocrinology 136:3774-3783.

Filby AL, Tyler CR. 2007. Cloning and characterization of cDNAs for hormones and/or receptors of growth hormone, insulin-like growth factor-I, thyroid hormone, and corticosteroid and the gender-, tissue-, and developmental-specific expression of their mRNA transcripts in fathead minnow (Pimephales promelas). Gen Comp Endocrinol 150: 151-163.

Gao X, Kalkhoven E, Peterson-Maduro J, van der Burg B, Destrée OHJ. 1994. Expression of the glucocorticoid receptor gene is regulated during early embryogenesis of Xenopus laevis. Biochim Biophys Acta 1218: 194-198.

Germain P, Staels B, Dacquet C, Spedding M, Laudet V. 2006. Overview of nomenclature of nuclear receptors. Pharmacol Rev 58:685-704.

Ghosh B, Wood CR, Held GA, Abbott BD, Lau C. 2000. Glucocorticoid receptor regulation in the rat embryo: a potential site for developmental toxicity? Toxicol. Appl Pharmacol 164:221-229.

Glennemeier KA, Denver RJ. 2002. Role for corticoids in mediating the response of Rana pipiens tadpoles to intraspecific competition. J Exp Zool 292:32-40.

Gomez F, Lahmame A, deKloet ER, Armario A. 1996. Hypothalamic- 
pituitary-adrenal response to chronic stress in five inbred rat strains: differential responses are mainly located at the adrenocortical level. Neuroendocrinology 63:327-337.

González A, Muñoza A, Muñoza M, Marína O, Smeets WJAJ. 1995. Ontogeny of vasotocinergic and mesotocinergic systems in the brain of the South African clawed frog Xenopus laevis J Chem Neuroanat 9:27-40.

Han F, Ozawa H, Matsuda K, Nishi M, Kawata M. 2005. Colocalization of mineralocorticoid receptor and glucocorticoid receptor in the hippocampus and hypothalamus. Neurosci Res 51:371-381.

Han F, Ozawa H, Matsuda KI, Lu H, De Kloet ER, Kawata M. 2007. Changes in the expression of corticotrophin-releasing hormone, mineralocorticoid receptor and glucocorticoid receptor mRNAs in the hypothalamic paraventricular nucleus induced by fornix transection and adrenalectomy. J Neuroendocrinol 19:229-238.

Herman JP, Adams D, Prewitt C. 1995. Regulatory changes in neuroendocrine stress integrative circuitry produced by a variable stress paradigm. Neuroendocrinology 61:180-190.

Herman JP, Figueiredo H, Mueller NK, Ulrich-Lai Y, Ostrander MM, Choi DC, Cullinan WE. 2003. Central mechanisms of stress integration hierarchical circuitry controlling hypothalamo-pituitary-adrenocortical responsiveness. Front Neuroendocrinol 24:151-180.

Herman JP, Ostrander MM, Mueller NK, Figueiredo H. 2005. Limbic system mechanisms of stress regulation: hypothalamo-pituitaryadrenocortical axis. Prog Neuropsychopharmacol Biol Psychiatry 29 1201-1213.

Hodgson ZG, Meddle SL, Roberts ML, Buchanan KL, Evans MR, Metzdorf R, Gahr M, Healy SD. 2007. Spatial ability is impaired and hippocampal mineralocorticoid receptor mRNA expression reduced in zebra finches (Taeniopygia guttata) selected for acute high corticosterone response to stress. Proc Biol Sci 274:239-245.

Holmes MC, Yau JLW, French KL, Seckl JR. 1995. The effect of adrenalectomy on 5-hydroxytryptamine and corticosteroid receptor subtype messenger-RNA expression in rat hippocampus. Neuroscience 64:327337.

Hu ZT, Yuri K, Morimoto M, Ozawa H, Kawata M. 1997a. Chronic loss of glucocorticoids following adrenalectomy down-regulates the expression of glucocorticoid receptor mRNA in the rat forebrain. Eur J Neurosci 9:1778-1783.

Hu ZT, Yuri K, Ozawa H, Lu HP, Yang YM, Ito T, Kawata M. 1997b. Adrenalectomy-induced granule cell death is predicated on the disappearance of glucocorticoid receptor immunoreactivity in the rat hippocampal granule cell layer. Brain Res 778:293-301.

Hügin-Flores ME, Steimer T, Aubert ML, Schulz P. 2004. Mineralo- and glucocorticoid receptor mRNAs are differently regulated by corticosterone in the rat hippocampus and anterior pituitary. Neuroendocrinology 79:174-184.

Iwasaki Y, Oiso Y, Saito H, Majzoub JA. 1997. Positive and negative regulation of the rat vasopressin gene promoter Endocrinology 138: $5266-5274$.

Kalman BA, Spencer RL. 2002. Rapid corticosteroid-dependent regulation of mineralocorticoid receptor protein expression in rat brain. Endocrinology 143:4184-4195.

Kononen J, Honkaniemi J, Gustafsson JA, Peltohuikko M. 1993. Glucocorticoid receptor colocalization with pituitary hormones in the rat pituitary gland. Mol Cell Endocrinol 93:97-103.

Kovács KJ, Westphal HM, Peczely P. 1989. Distribution of glucocorticoid receptor-like immunoreactivity in the brain, and its relation to $\mathrm{CRF}$ and ACTH immunoreactivity in the hypothalamus of the japanese quail, Coturnix coturnix japonica. Brain Res 505:239-245.

Krain LP, Denver RJ. 2004. Developmental expression and hormonal regulation of glucocorticoid and thyroid hormone receptors during metamorphosis in Xenopus laevis. Journal of Endocrinology 181(1):91104.

Kumar R, Thompson EB. 2005. Gene regulation by the glucocorticoid receptor: structure:function relationship. J Steroid Biochem Mol Biol 94:383-394.

Kwok AHY, Wang Y, Wang CY, Leung FC. 2007. Cloning of chicken glucocorticoid receptor (GR) and characterization of its expression in pituitary and extrapituitary tissues. Poult Sci 86:423-430.

Licht P, McCreery BR, Barnes R, Pang R. 1983. Seasonal and stress related changes in plasma gonadotropins, sex steroids, and corticosterone in the bullfrog, Rana catesbeiana. Gen Comp Endocrinol 50:124145

Loh YP, Myers B, Wong B, Parish DC, Lang M, Goldman ME. 1985. Regulation of pro-opiomelanocortin synthesis by dopamine and cAMP in the amphibian pituitary intermediate lobe. J Biol Chem 260:89568963.

Lupien SJ McEwen BS. 1997. The acute effects of corticosteroids on cognition: integration of animal and human model studies. Brain Res Rev 24:1-27

Makino S, Gold PW, Schulkin J. 1994. Effects of corticocosterone on CRH messenger RNA and content in the bed nucleus of the stria terminalis-comparison with the effects in the central nucleus of the amygdala and the paraventricular nucleus of the hypothalamus. Brain Res 657(1-2):141-149.

Makino S, Smith MA, Gold PW. 1995. Increased expression of corticotropin-releasing hormone and vasopressin messenger ribonucleic acid (mRNA) in the hypothalamic paraventricular nucleus during repeated stress: association with reduction in glucocorticoid receptor mRNA levels. Endocrinology 136:3299-3309.

Makino S, Hashimoto K, Gold PW. 2002a. Multiple feedback mechanisms activating corticotropin-releasing hormone system in the brain during stress. Pharmacol Biochem Behav 73:147-158.

Makino S, Smith MA, Gold PW. 2002b. Regulatory role of glucocorticoids and glucocorticoid receptor mRNA levels on tyrosine hydroxylase gene expression in the locus coeruleus during repeated immobilization stress. Brain Res 943:216-223

Marín O, Smeets WJAJ, González A. 1998. Basal ganglia organization in amphibians: chemoarchitecture. J Comp Neurol 392:285-312.

Meyer AS, Schmidt TJ. 1995. Potential mechanisms underlying autoregulation of glucocorticoid receptor mRNA levels in the DHD/K12/PROb rat colonic adenocarcinoma cell line. J Steroid Biochem Mol Biol 55 $219-228$

Morimoto M, Morita N, Ozawa H, Yokoyama K, Kawata M. 1996. Distribution of glucocorticoid receptor immunoreactivity and mRNA in the rat brain: an immunohistochemical and in situ hybridization study. Neurosci Res 26:235-269.

Nishimura K, Makino S, Tanaka Y, Kaneda T, Hashimoto K. 2004. Altered expression of p53 mRNA in the brain and pituitary during repeated immobilization stress: negative correlation with glucocorticoid receptor mRNA levels. J Neuroendocrinol 16:84-91.

O'donnell D, Francis D, Weaver S, Meaney MJ. 1995. Effects of adrenalectomy and corticosterone replacement on glucocorticoid receptor levels in rat brain tissue: a comparison between Western blotting and receptor binding assays. Brain Res 687:133-142.

Okret S, Poellinger L, Dong Y, Gustafsson JA. 1986. Down-regulation of glucocorticoid receptor mRNA by glucocorticoid hormones and recognition by the receptor of a specific binding sequence within a receptor cDNA clone. Proc Natl Acad Sci U S A 83:5899-5903.

Okret S, Dong Y, Bronnegard M, Gustafsson JA. 1991. Regulation of glucocorticoid receptor expression. Biochimie 73:51-59.

Ozawa H, Ito T, Ochiai I, Kawata M. 1999. Cellular localization and distribution of glucocorticoid receptor immunoreactivity and the expression of glucocorticoid receptor messenger RNA in rat pituitary gland. Cell Tissue Res 295:207-214.

Pratt WB, Toft DO. 1997. Steroid receptor interactions with heat shock protein and immunophilin chaperones. Endocrine Rev 18:306-360.

Pudney M, Varma MGR, Leake CJ. 1973. Establishment of a cell line (XTC-2) from South African clawed toad, Xenopus laevis. Experientia 29:466-467.

Reul J, Pearce PT, Funder JW, Krozowski ZS. 1989. Type I and type II corticosteroid receptor gene expression in the rat: effect of adrenalectomy and dexamethasone administration. Mol Endocrinol 3:16741680.

Rosenfeld P, Vaneekelen JAM, Levine S, Dekloet ER. 1988. Ontogeny of the type 2 glucocorticoid receptor in discrete rat brain regions: an immunocytochemical study. Brain Res Dev Brain Res 42:119-127.

Rosewicz S, McDonald AR, Maddux BA, Goldfine ID, Miesfeld RL, Logsdon CD. 1988. Mechanism of glucocorticoid receptor down-regulation by glucocorticoids. J Biol Chem 263:2581-2584.

Sapolsky RM. 2003. Stress and plasticity in the limbic system. Neurochem Res 28:1735-1742.

Sapolsky RM, Krey LC, McEwen BS. 1984. Stress down-regulates corticosterone receptors in a site-specific manner in the brain. Endocrinology 114:287-292

Seger MA, van Eekelen JA, Kiss JZ, Burbach JP, de Kloet ER. 1988. Stimulation of pro-opiomelanocortin gene expression by glucocorticoids in the denervated rat intermediate pituitary gland. Neuroendocrinology 47:350-357.

Sheppard KE, Autelitano DJ, Roberts JR, Blum M. 1993. Glucocorticoid 
receptor function in rat pituitary intermediate lobe is inhibited by an endogenous protein. J Neuroendocrinol 5:195-200.

Silva CM, Powelloliver FE, Jewell CM, Sar M, Allgood VE, Cidlowski JA. 1994. Regulation of the human glucocorticoid receptor by long-term and chronic treatment with glucocorticoid. Steroids 59:436-442.

Spencer RL, Kalman BA, Cotter CS, Deak T. 2000. Discrimination between changes in glucocorticoid receptor expression and activation in rat brain using Western blot analysis. Brain Res 868:275-286.

Tagawa M, Hagiwara H, Takemura A, Hirose S, Hirano T. 1997. Partial cloning of the hormone-binding domain of the cortisol receptor in tilapia, Oreochromis mossambicus, and changes in the mRNA level during embryonic development. Gen Comp Endocrinol 108:132-140.

Teitsma CA, Anglade I, Toutirais G, Munoz-Cueto JA, Saligaut D, Ducouret B, Kah O. 1998. Immunohistochemical localization of glucocorticoid receptors in the forebrain of the rainbow trout (Oncorhynchus mykiss). J Comp Neurol 401:395-410.

Thornton JW. 2001. Evolution of vertebrate steroid receptors from an ancestral estrogen receptor by ligand exploitation and serial genome expansions. Proc Natl Acad Sci U S A 98:5671-5676.

Tokuda Y, Touhata K, Kinoshita M, Toyohara H, Sakaguchi M, Yokoyama Y, Ichikawa T, Yamashita S. 1999. Sequence and expression of a cDNA encoding Japanese flounder glucocorticoid receptor. Fisheries Sci 65 $466-471$.

Tuinhof R, Ubink R, Tanaka S, Atzori C, van Strien FJC, Roubos EW. 1998. Distribution of pro-opiomelanocortin and its peptide end products in the brain and hypophysis of the aquatic toad, Xenopus laevis. Cell Tissue Res 292:251-265.
Vedeckis WV, Ali M, Allen HR. 1989. Regulation of glucocorticoid receptor protein and mRNA levels. Cancer Res 49:S2295-S2302.

Visser DTM, Hu ZT, Pasterkamp RJ, Morimoto M, Kawata M. 1996. The alteration of glucocorticoid receptor-immunoreactivity in the rat forebrain following short-term and long-term adrenalectomy. Brain Res 729:216-222

Watlington CO, Perkins F, Munson PJ, Handler J. 1982. Aldosterone and corticosterone binding and effects on $\mathrm{Na}^{+}$transport in cultured kidney cells. Am J Physiol 242:F610-F619.

Webster JC, Jewell CM, Bodwell JE, Munck A, Sar M, Cidlowski JA. 1997. Mouse glucocorticoid receptor phosphorylation status influences multiple functions of the receptor protein. J Biol Chem 272:9287-9293.

Wei Q, Lu XY, Liu L, Schafer G, Shieh KR, Burke S, Robinson TE, Watson SJ, Seasholtz AF, Akil H. 2004. Glucocorticoid receptor overexpression in forebrain: a mouse model of increased emotional lability. Proc Nat Acad Sci U S A 101:11851-11856.

Yao M, Westphal NJ, Denver RJ. 2004. Distribution and acute stressorinduced activation of corticotrophin-releasing hormone neurones in the central nervous system of Xenopus laevis. J Neuroendocrinol 16:880 893.

Yao M, Stenzel-Poore M, Denver RJ. 2007. Structural and functional conservation of vertebrate corticotropin-releasing factor genes: evidence for a critical role for a conserved cyclic AMP response element. Endocrinology 148:2518-2531.

Yao M, Schulkin J, Denver RJ. 2008. Evolutionarily conserved glucocorticoid regulation of corticotropin-releasing factor expression. Endocrinology (in press). 